\title{
Intraventricular Administration of BDNF Increases Neuropeptide Expression in Newborn Rat Brain
}

\author{
Hiroyuki Nawa, ${ }^{1}$ Mary A. Pelleymounter, ${ }^{2}$ and Josette Carnahan ${ }^{2}$ \\ 'Beckman Neuroscience Center, Cold Spring Harbor Laboratory, Cold Spring Harbor, New York 11724 and ${ }^{2}$ Amgen \\ Center, Thousand Oaks, California 91320
}

Brain-derived neurotrophic factor (BDNF) specifically enhances and maintains the expression of neuropeptide Y (NPY) and somatostatin (SOM) in cultured neocortical neurons (Nawa et al., 1993). In this article, we examined its effects in vivo on neuropeptide expression in various brain regions by injecting BDNF into the cerebroventricle of newborn rats. Repeated administration ( $2 \times)$ of BDNF increased contents of NPY-like immunoreactivity (NPY-LI) and substance P (SP)LI most markedly in the anterior neocortex by 11- and 24fold, respectively, in comparison to values in the animals receiving control injection. A smaller but significant increase was also observed in immunoreactivity for somatostatin (SOM), enkephalin (ENK), and cholecystokinin (CCK). mRNA for NPY, SP, and SOM was similarly upregulated in the anterior neocortex, suggesting that BDNF enhances peptide synthesis rather than inhibiting peptide release or degradation. Among the brain regions examined, however, peptidergic responses to BDNF were different with respect to their spatial distribution and time course. Induction of SP-LI, NPY-LI, and SOM-LI around the injection site was most pronounced in cortical layers II/III, layers IV-VI, and layer VI, respectively. Peptidergic immunoreactivity was also enhanced in other brain regions ipsilateral to the injection site, for example, NPY-LI in the hippocampus, thalamic nuclei, and striatum, and SOM-LI in the striatum. A single injection of BDNF elevated SP-LI to a plateau level within $12 \mathrm{hr}$ while NPY-LI and SOM-LI reached maximum levels at $48 \mathrm{hr}$, and then all returned to control levels at $68 \mathrm{hr}$. In contrast, the same dose of NGF had no influences on the neuropeptide levels at $48 \mathrm{hr}$. These observations suggest that BDNF regulates the development of neuropeptide expression in the CNS in a plastic manner.

[Key words: brain-derived neurotrophic factor, cerebral cortex, cholecystokinin, enkephalin, neuropeptide $Y$, substance $P$, somatostatin]

The expression of neurotransmitters and neuropeptides is regulated precisely in a spatial and temporal manner during development (see Hökfelt, 1991). Previous studies on the PNS have suggested that the production of neuropeptides is dynam-

\footnotetext{
Received June 23, 1993; revised Oct. 26, 1993; accepted Nov. 30, 1993.

We thank J. Miller for his encouragement, C. Gall and S. McConnell for valuable suggestions, and S. Sabol, Y. Takahashi, and D. Helfman for cDNA probes. This work is in part supported by Cold Spring Harbor Laboratory Start-Up Funds and Klingenstein Fellowship Award to H.N.

Correspondence should be addressed to Hiroyuki Nawa, Beckman Neuroscience Center, Cold Spring Harbor I aboratory, One Bungtown Road, Cold Spring Harbor, NY 11724

Copyright C 1994 Society for Neuroscience $0270-6474 / 94 / 143751-15 \$ 05.00 / 0$
}

ically influenced by diffusible protein factors that arc synthesized by many cell types including glial cells, target cells, and hematopoietic cells (for review, see Patterson and Nawa, 1993). For example, NGF controls the expression of substance $\mathrm{P}$ and calcitonin gene-related peptide (CGRP) in cultured sensory neurons (Lindsay and Harmar, 1989). Cholinergic differentiation factor (leukemia inhibitory factor, or LIF) and ciliary neurotrophic factor (CNTF) alter neurotransmitter and peptide phenotypes in sympathetic neurons (LIF: Fukada, 1985; Yamamori et al., 1989; Nawa et al., 1990; CNTF: Ernsberger et al., 1989; Saadat et al., 1989; Rao et al., 1992). Ciliary parasympathetic neurons initiate SOM expression by reacting with activin (Coulombe et al., 1993). These activities can be observed not only during normal PNS development but also induced in response to nerve injury and inflammation (Jonakait and Schotland, 1990; Freidin and Kessler, 1991; Hyatt-Sachs et al., 1993). These observations in the PNS suggested the possibility that diffusible protein factors could also control expression of neuropeptides in the CNS.

Many pharmacological and physiological studies have demonstrated that neuropeptide expression in the CNS can be regulated by drugs (Bannon et al., 1987; Tempel et al., 1990; Gerfen et al., 1991; Wahlestedt et al., 1991), steroid hormones (Simerly et al., 1987, 1989; Baldino et al., 1988; Kasper et al., 1992), and neuronal activity (Hendry et al., 1988; Agoston et al., 1991 ; Lindefors et al., 1991). Since diffusible protein factors are known to mediate such alterations in neuropeptide expression in the PNS (Fukada 1980; Rao et al., 1992; Shadiack et al., 1992), their effects observed in the CNS could also be indirect to neurons and mediated by such protein factors. However, it has been less clear how diffusible protein factors are involved in regulation of neuropeptide expression in the CNS.

Brain-derived neurotrophic factor (BDNF) was initially identified by its neurotrophic activity on peripheral neurons (Barde et al., 1982), and its molecular structure has recently been elucidated by cDNA cloning: BDNF, as well as neurotrophin-3 (NT-3), is structurally related to NGF (Leibrock et al., 1989; Hohn et al., 1990; Maisonpierre et al., 1990a; Yancopoulos et al., 1990). Much interest is now concentrated on these neurotrophic factors in the NGF family with respect to their potential therapeutic application to neurological diseases. mRNA for BDNF and its receptors (trkB gene product) are abundantly expressed throughout the CNS, particularly in the hippocampus and cerebral cortex (Klein et al., 1989, 1990). This suggests physiological importance of BDNF in many brain regions, although the nature of neuronal response to BDNF remained to be characterized. Neurotransmitter differentiation activity of neurotrophins has been found in septal and striatal neurons: 
NGF and BDNF increase ChAT activity (Hefti et al., 1985; Martinez et al., 1985; Mobley et al., 1985; Alderson et al., 1990; Knüsel et al., 1991). We have shown that BDNF, but not NGF, regulates neuropeptide expression in cultured neocortical neurons without affecting neuronal survival (Nawa et al., 1992). The effect of BDNF was dependent on its concentration in culture, and specific for the neuropeptides expressed in neocortical GABAergic neurons (Nawa et al., 1993). This suggests that BDNF may also play a role in the control of peptidergic expression in the CNS. In the present study, we analyzed the effect in vivo of exogenous BDNF on neuropeptide expression in various brain regions and discussed potential contribution of BDNF to peptidergic development in the CNS.

\section{Materials and Methods}

Animal and surgical procedures. Newborn Sprague-Dawley rats 1-2 d after birth (Charles River or Taconic Farms) were anesthetized by hypothermia according to Kuhlengel et al. (1990). The pups were secured to a plaster mold installed in a stereotaxic device (Kopf Instruments, Tuyunga, CA). A 28 gauge stainless steel cannula (Plastic One Inc., Roanokc, VA) was lowered stereotaxically into the lateral ventricle $(0.6$ $\mathrm{mm}$ anterior to bregma, $0.8 \mathrm{~mm}$ lateral to midline, and $2.7 \mathrm{~mm}$ below skull). This position conforms to the anterior end of the lateral ventricle according to the brain atlas of a newborn rat (Paxinos et al., 1991) (see also Fig. 1). Two microliters of recombinant human BDNF $(10 \mathrm{mg} / \mathrm{ml})$, control protein (turkey immunoglobulin, $50 \mathrm{mg} / \mathrm{ml}$ ), or saline were injected over $2 \mathrm{~min}$ from a $10 \mathrm{ml}$ Hamilton syringe that attached to the cannula. However, some leakage of the samples with cerebrofluids was unavoidable during and after injection, because the thickness of cerebral cortex surrounding the ventricle is quite thin (about $1 \mathrm{~mm}$ ) at neonatal stages. Thus, the actual volume of the sample injected and stayed in the ventricle was calibrated by adding an iodinated protein $(2000 \mathrm{cpm}$ of ${ }^{125}$ I-NPY) into the BDNF solution. This demonstrated that this procedure enabled us to constantly deliver $0.74 \pm 0.11 \mu \mathrm{l}(n=6)$ of a sample solution into the nconatal ventricle. For the first series of experiments, the injection was repeated with the same procedures $2 \mathrm{~d}$ after the first injection. One day after the second injection (postnatal day 5), the pups were killed by $\mathrm{CO}_{2}$ exposure for peptide measurement, RNA analysis and immunohistochemistry. The total amount of BDNF (approximately $14 \mu \mathrm{g}$ ), which was administered over the $3 \mathrm{~d}$ period, was determined according to the doses of neurotrophins whose cerebroventricular injections were reported previously $(30 \mu \mathrm{g} \mathrm{NGF} /$ injection, Mobley et al., 1985; $12 \mu \mathrm{g} \mathrm{BDNF} / \mathrm{d}$, Alter et al., 1992; $4.5 \mu \mathrm{g} \mathrm{BDNF} /$ d, Knüsel et al., 1992). For controls, we used unoperated rat pups at the same age of the operated rats.

To determine the time course and the dose response, BDNF as well as NGF was administered only once on postnatal day 2 , and the brains were dissected after given time periods. We did not observe apparent bchavioral abnormality of the animals after these treatments. However, five rats having infection were removed from subsequent analyses. Both BDNF and NGF used for injection was produced in a Chinese hamster ovary cell line and purified to homogeneity as described previously (DiStefano et al., 1992).

Transmitter/peptide measurement. Brains were taken and immediately transferred into ice-cold Leibovitz (L-15) medium. Under a dissection microscope, anterior cortex (anterior half including the corpus callosum), posterior cortex (posterior half excluding the corpus callosum), hippocampus, striatum, and hypothalamus were dissected from each brain hemisphere. Each sample was weighed and homogenized with $10 \times$ volume $(10 \mu \mathrm{l} / \mathrm{mg}$ wet tissue) of $50 \mathrm{~mm}$ acetic acid containing 1 mM EDTA by trituration with a $200 \mu$ l pipetman tip. The homogenates were boiled for $5 \mathrm{~min}$ to inactivate proteases and then centrifuged. The supernatants werc storcd at $20^{\circ} \mathrm{C}$ in siliconized microtubes until use. Peptide immunoreactivity was measured by liquid phase radioimmunoassay using ${ }^{125}$ I-labeled peptide (Du Pont-New England Nuclear, Boston, MA) and anti-peptide antibodies (Amersham, Arlington Height, IL, or Cambridge Research Biologicals Inc., Northwich, UK) as described previously in detail (Nawa and Sah, 1990). The radioimmunoassay system had the sensitive range of $10-1000 \mathrm{pg}$ for NPY, $1-100$ pg for SP, 3-300 pg for SOM, 1-100 pg for ENK, and 1-100 pg for CCK. Peptide authenticity was previously confirmed by HPLC (Nawa and Sah, 1990).
Northern blotting. Total RNA was extracted from brain tissues by an acid-phenol method (Sambrook et al., 1989). KNA samples (10 $\mu \mathrm{g})$ were denatured in $50 \%$ formamide, $6 \%$ formaldehyde, $20 \mathrm{mM}$ MOPS buffer $(\mathrm{pH} 7.0), 1 \mathrm{~mm}$ EDTA at $65^{\circ} \mathrm{C}$ for $10 \mathrm{~min}$ and fractionated on a formaldehyde-agarose gel (Sambrook et al., 1989). RNA in a gel was treated with water for $30 \mathrm{~min}$ and transferred onto Biodyne nylon membrane (Pall Scientific, East Hills, NY) with $20 \times$ saline-sodium citrate (SSC) buffer and fixed by exposure to ultraviolet light (Stratalinker, Stratagene Inc.). ${ }^{32} \mathrm{P}$-labeled cDNA probes were generated using the hexanucleotide random priming method (Feinberg and Vogelstein, 1983). Hybridization was carried out at $42^{\circ} \mathrm{C}$ for $12-18 \mathrm{hr}$ in a solution containing $50 \%$ formamide, $5 \times$ SSC, $5 \times$ Denhardt's solution, and $1 \%$ SDS. The membranes were washed with $0.3 \times \mathrm{SSC}, 1 \% \mathrm{SDS}$ at $65^{\circ} \mathrm{C}$. Radioaclivity of a positive RNA band was measured by a Fuji Bioimage Analyzer (Fuji Medical System, Stanford, CT). The membranes were also exposed on $\mathrm{X}$-ray film for display

cDNA probes for NPY, CCK, and $\beta$-actin mRNAs were given by Dr. Sabol (Higuchi et al., 1988), Drs. Takahashi and Kuwano (Kuwano et al., 1984), and Dr. Helfman, respectively. All the cDNA probes were prepared to be 400-600 nucleotides long as described previously (Nawa and Sah, 1990).

Immunostaining of neuropeptides. Brains were fixed in 4\% paraformaldehyde solution in $0.1 \mathrm{~m}$ sodium phosphate buffer $(\mathrm{pH} 7.3)$ for 24 $48 \mathrm{hr}$, and then immersed in $15 \%$ sucrose for $1 \mathrm{~d}$ and then $30 \%$ sucrose for $3 \mathrm{~d}$. Frozen sections $(20 \mu \mathrm{m})$ were cut coronally with a cryostat (Leitz, Germany) and placed on gelatin-coated slides. For staining of neuropeptide-LI, sections were rinsed with phosphate-buffered saline (PBS) several times, and endogenous peroxidase was inactivated with $0.1 \mathrm{M}$ sodium periodate for $10 \mathrm{~min}$ followed by $10 \mathrm{mg} / \mathrm{ml}$ sodium borohydrate for $15 \mathrm{~min}$. This step was essential for this staining procedure since trapped red blood cells containing a significant amount of peroxidase activity. All the sections were preabsorbed with $5 \%$ goat serum for $1 \mathrm{hr}$ at room temperature prior to incubation with antisera. Rabbit antisera directed against SP, NPY, and SOM (Amersham, Arlington Height, IL) were diluted to $1: 1000$ with $3 \%$ goat serum in 0.5 $\mathbf{M ~ N a C l}, 10 \mathrm{~mm}$ sodium phosphate (pH 7.3), and $0.05 \%$ Triton X-100 and put on sections for overnight at $4^{\circ} \mathrm{C}$. The sections were then incubated with a biotinylated goat anti-rabbit IgG antibody (Vector, Burlingame, CA), followed by the avidin-biotin-peroxidase complex (Vectastain $\mathrm{ABC}$ kit, Vector). The peroxidase activity was visualized by

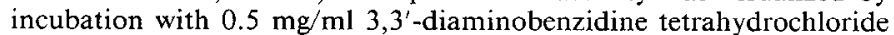
in $0.1 \mathrm{M}$ sodium acetate buffer $(\mathrm{pH} 7.0)$ containing $2 \%$ nickel sulfate. Preincubation of the anti-peptide antisera with excess amounts of synthetic peptides abolished the immunostaining as described previously (Nawa and Sah, 1990). The route of the cannula in sections was identified with a pitted cortical surface in the right frontal cortex and red blood cells remaining in the route.

Immunostaining of BDNF. Anti-BDNF antisera were produced by immunizing turkeys with the purified human recombinant BDNF; 200 $\mu \mathrm{g}$ of BDNF in complete Freund's adjuvant was injected subcutaneously into four adult turkeys every month. The titer of the antisera was monitored by an ELISA and specificity of the antisera was confirmed by Western blotting using recombinant NGF, NT-3, and BDNF. All bleeds used in this report were highly specific in these assays and did not show any cross-reactivity to NGF nor NT-3 (data not shown).

At 10,24, and $48 \mathrm{hr}$ after BDNF injection, the brains were fixed with the paraformaldehyde solution and coronal sections $(50 \mu \mathrm{m})$ were made from the fixed brains. Sections were treated with a blocking solution containing $4 \%$ normal rabbit serum, $0.1 \%$ Triton $X-100,1 \%$ bovine serum albumin (Sigma) in $50 \mathrm{~mm}$ potassium phosphate buffer ( $\mathrm{pH} 7.4$ ). The turkey anti-BDNF antisera diluted 1:2500 were added to the sections overnight at $4^{\circ} \mathrm{C}$. The sections were then incubated with a biotinylated rabbit anti-chicken/turkey Ig antibody diluted 1:1500 (Zymed, San Francisco, CA), followed by the avidin-biotin-peroxidase complex (Vectastain ABC kit, Vector). The peroxidase activity was visualized with $3,3^{\prime}$-diaminobenzidine tetrahydrochloride as described above.

\section{Results}

Increases of neuropeptides with intraventricular injection of $B D N F$

To monitor the performance of the cerebroventricular administration, dye solution was injected into anterior end of the lateral ventricle through the frontal cortex (Fig. 1 $A$ ). It spread 

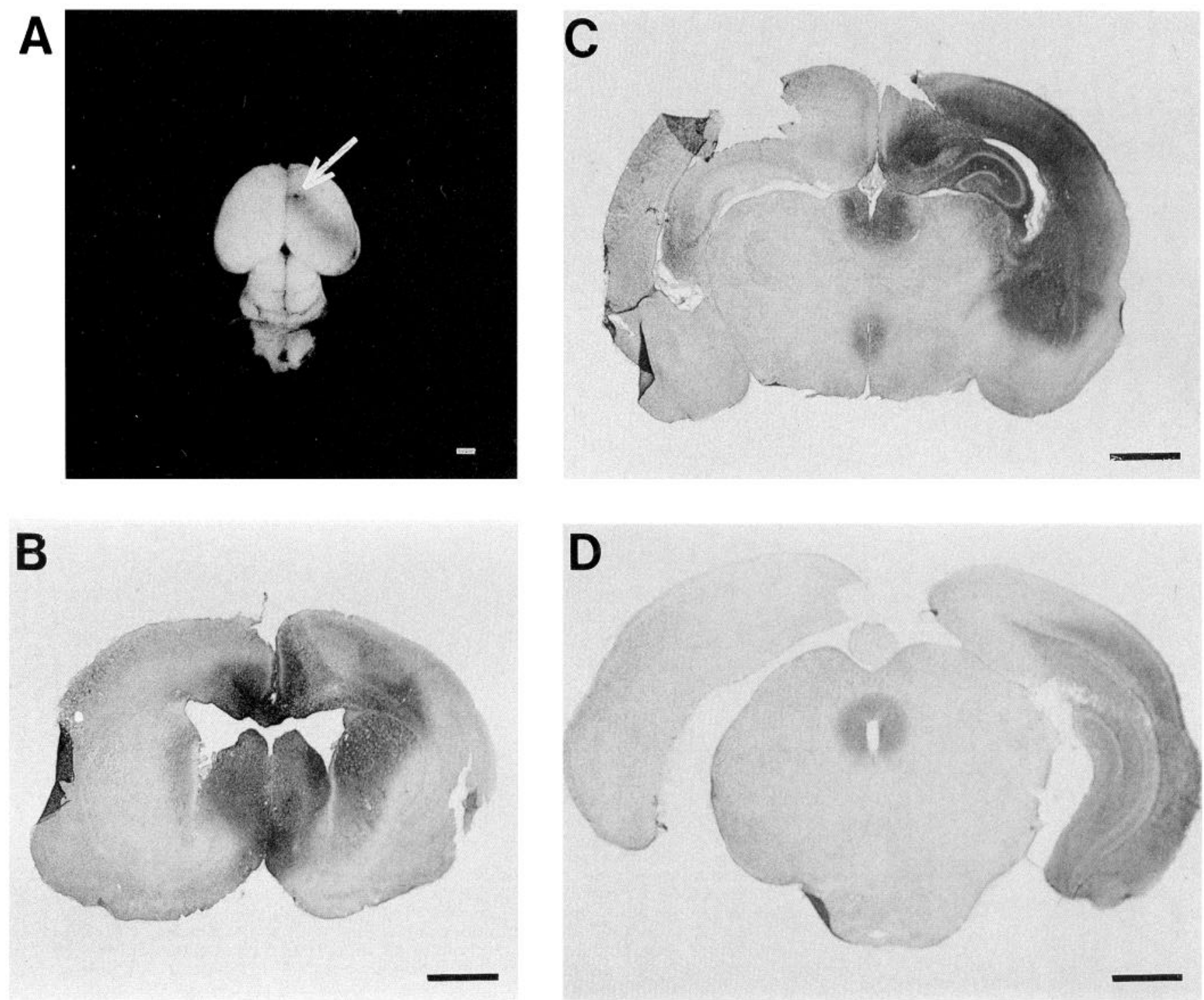

Figure 1. Diffusion of dye and BDNF injected into the lateral ventricle of newborn rats. $A$, Dye solution $(0.7 \mu 1$ of $1 \%$ bromophenolblue) was injected into the right lateral ventricle through the anterior frontal cortex. Physical diffusion of the dye was photographed in the brain 1 hr after dye administration. An arrow marks the position into which the cannula was inserted. $B-D$, Ten hours after approximately $7 \mu \mathrm{g}$ of BDNF was injected, BDNF diffusion was examined with immunostaining with anti-BDNF antisera. Coronal brain sections were cut through the striatum $(B)$, the hippocampus $(C)$, and substantia nigra $(D)$. Scale bars, $1 \mathrm{~mm}$.

over all the lateral ventricular region within $1 \mathrm{hr}$. Using an immunohistochemical technique with anti-BDNF antiserum, we also confirmed the area where BDNF was distributed after injection. Ten hours after BDNF injection, BDNF significantly diffused into the brain tissues ipsilateral to the injection hemisphere: BDNF-LI was detected in neocortex, septal, hippocampus, and striatum (Fig. $1 B-D$ ). BDNF-LI was also found around the third ventricle, suggesting that BDNF reached some areas of the hypothalamus and lower brainstem. However, diffusion of $\mathrm{BDNF}$ as well as the dye into contralateral ventricle appeared to be very limited. A similar spatial distribution of BDNF-LI was observed with a weaker staining intensity $24 \mathrm{hr}$ after injection, while BDNF-LI disappeared after $48 \mathrm{hr}$ (data not shown).

To optimize the effects of BDNF, we injected BDNF twice with $2 \mathrm{~d}$ interval. Twenty to $25 \mathrm{hr}$ after the second injection, peptide levels were measured by radioimmunoassay in the following five brain regions, anterior neocortex, posterior neocor- tex, hippocampus, striatum, and hypothalamus (Table 1). The injection of saline and control protein had no effects on neuropeptide levels in all of the brain regions except CCK-LI in posterior neocortex and SP-LI in hypothalamus.

In the anterior neocortex, intraventricular BDNF had greatest effects on all the neuropeptide levels examined, particularly NPYLI and SP-LI: NPY-LI and SP-LI were increased 10 and 24 times over control values in the BDNF-injected hemisphere, respectively. The contents of NPY-LI and SP-LI increased were almost comparable to their contents in rat adult neocortex (Kanazawa and Jessel, 1976; Allen et al., 1983). The effects on NPYLI and SP-LI were widespread over many other brain regions. Smaller but significant upregulation of SOM-LI was found in anterior and posterior neocortex, and striatum. The magnitude of the increases of SOM-LI in contralateral hemispheres was comparable to that in the ipsilateral hemispheres, while increases of both NPY-LI and SP-LI in the contralateral hemisphere 


\begin{tabular}{|c|c|c|c|c|c|}
\hline $\begin{array}{l}\text { Regions/ } \\
\text { conditions }\end{array}$ & NPY & SOM & SP & ENK & $\mathrm{CCK}$ \\
\hline \multicolumn{6}{|l|}{ Anterior neocortex } \\
\hline Unoperated (6) & $45 \pm 5$ & $36 \pm 1.8$ & $0.5 \pm 0.03$ & $0.86 \pm 0.03$ & $3.13 \pm 0.19$ \\
\hline Saline (6) & $42 \pm 5$ & $37 \pm 4.0$ & $0.5 \pm 0.06$ & $0.60 \pm 0.07$ & $2.64 \pm 0.15$ \\
\hline BDNF, ipsi (5) & $532 \pm 23^{a}$ & $123 \pm 8.0^{a}$ & $12.9 \pm 0.90^{a}$ & $2.75 \pm 0.18^{a}$ & $6.90 \pm 0.50^{a}$ \\
\hline BDNF, contra (5) & $310 \pm 59$ & $109 \pm 6.3$ & $6.0 \pm 0.65^{a}$ & $1.99 \pm 0.14$ & $5.10 \pm 0.35$ \\
\hline \multicolumn{6}{|l|}{ Posterior neocortex } \\
\hline Unoperated (6) & $37 \pm 5$ & $35 \pm 3.1$ & $0.9 \pm 0.07$ & $0.92 \pm 0.07$ & $2.76 \pm 0.15$ \\
\hline Saline (5) & $25 \pm 2$ & $43 \pm 4.0$ & $0.7 \pm 0.08$ & $0.65 \pm 0.03$ & $2.07 \pm 0.10^{r}$ \\
\hline BDNF, ipsi (5) & $218 \pm 13^{a}$ & $86 \pm 6.0^{a}$ & $4.8 \pm 0.47^{a}$ & $1.99 \pm 0.26^{b}$ & $4.08 \pm 0.37^{b}$ \\
\hline BDNF, contra (5) & $104 \pm 19^{\prime}$ & $72 \pm 6.0$ & $1.9 \pm 0.20^{a}$ & $1.29 \pm 0.10$ & $3.79 \pm 0.40$ \\
\hline \multicolumn{6}{|l|}{ Striatum } \\
\hline Unoperated (6) & $56 \pm 4$ & $35 \pm 2.7$ & $16.8 \pm 1.1$ & $33.6 \pm 2.3$ & $1.81 \pm 0.16$ \\
\hline Saline (6) & $59 \pm 5$ & $32 \pm 4.4$ & $14.4 \pm 1.8$ & $25.8+4.3$ & $1.72+0.10$ \\
\hline BDNF, ipsi (4) & $312 \pm 19^{a}$ & $84 \pm 5.3^{a}$ & $36.5 \pm 3.2^{a}$ & $47.7 \pm 5.6$ & $4.76 \pm 0.29^{a}$ \\
\hline BDNF, contra (5) & $138 \pm 25^{b}$ & $51 \pm 5.2$ & $21.5 \pm 1.9^{c}$ & $33.6 \pm 5.9$ & $3.48 \pm 0.49$ \\
\hline \multicolumn{6}{|l|}{ Hippocampus } \\
\hline Unoperated (6) & $61 \pm 4$ & $31 \pm 2.4$ & $2.2 \pm 0.12$ & $1.10 \pm 0.10$ & $4.59 \pm 0.24$ \\
\hline Saline (6) & $80 \pm 6$ & $35 \pm 3.7$ & $1.8 \pm 0.13$ & $0.88 \pm 0.15$ & $3.53 \pm 0.28$ \\
\hline BDNF, ipsi (5) & $304 \pm 31^{a}$ & $67 \pm 9.0$ & $3.6 \pm 0.27^{a}$ & $1.93 \pm 0.23$ & $3.94 \pm 0.41$ \\
\hline BDNF, contra (5) & $243 \pm 18$ & $58 \pm 5.2$ & $2.9 \pm 0.27$ & $1.58 \pm 0.13$ & $4.30 \pm 0.30$ \\
\hline \multicolumn{6}{|l|}{ Hypothalamus } \\
\hline Unoperated (3) & $271 \pm 26$ & $153 \pm 10$ & $30.4 \pm 0.9$ & $15.8 \pm 0.4$ & $3.60 \pm 0.21$ \\
\hline Saline (6) & $336 \pm 16$ & $107 \pm 5$ & $23.7 \pm 0.6^{a}$ & $13.2 \pm 0.4$ & $4.11 \pm 0.36$ \\
\hline BDNF (4) & $356 \pm 47$ & $156 \pm 14$ & $38.8 \pm 3.6^{b}$ & $23.6 \pm 2.4^{b}$ & $6.43 \pm 0.55$ \\
\hline
\end{tabular}

Saline, BDNF $(7.4 \pm 1.1 \mu \mathrm{g})$, or control protein $(37 \pm 5.5 \mu \mathrm{g})$ was injected into the right lateral ventricle of newborn rats on postnatal days 2 and 4 . On postnatal day 5 , peptide levels were determined in the following brain regions in the injected hemisphere (ipsi); anterior neocortex (including the frontal and parietal cortex), posterior neocortex (parietal, temporal, occipital, and entorhinal cortices including the amygdala), hippocampus, striatum, and hypothalamus. Only from the BDNF-administered rats, the brain tissues in contralateral side (contra) were also analyzed. After extraction of peptides with the acetic acid solution, peptide levels of NPY-LI, SOM-LI, SP-LI, ENK-LI, and CCK-LI were measured by radioimmunoassay. Given data represent mean $\pm \mathrm{SEM} \mathrm{pg} / \mathrm{mg}$ tissue. Numbers of animals analyzed are shown in parentheses. All the data were reproduced in other independent experiments. In the anterior neocortex of the rats receiving control protein $(n=6)$, content of NPY-LI was $57.3 \pm 2.6 \mathrm{pg} / \mathrm{mg}$ and that of SOM-LI was $45.6 \pm 5.1 \mathrm{pg} /$ $\mathrm{mg}$. Statistical analysis was performed for the three experimental groups (unoperated vs saline vs BDNF) using an ANOVA. Except for NPY and SOM in hypothalamus, CCK and ENK in hippocampus, and ENK in striatum, all neuropeptide levels in other brain regions exhibited significant influence of the treatments $(p<0.010)$. Second, an influence of each treatment, as well as its effect on the contralateral hemisphere, was analyzed with Student's $t$ test for individual pairs (i.e., normal vs saline, saline vs BDNF, and ipsilateral hemisphere vs contralateral hemisphere). Each result is listed as superscript letters on the peptide values of the latter experimental groups.

${ }^{a} p<0.001$.

$p<0.005$

$p<0.01$.

Table 2. Effects of BDNF on neuropeptide mRNAs in the anterior neocortex

\begin{tabular}{lllllll} 
Samples & NPY mRNA & SOM mRNA & SP mRNA & ENK mRNA & CCK mRNA & $\begin{array}{l}\beta-A c t i n \\
\text { mRNA }\end{array}$ \\
\hline Saline & $163 \pm 12$ & $197 \pm 15$ & $36.6 \pm 3.5$ & $23.0 \pm 4.9$ & $52.7 \pm 2.2$ & $959 \pm 25$ \\
BDNF & $686 \pm 58$ & $953 \pm 72$ & $243 \pm 25$ & $42.7 \pm 7.4$ & $70.7 \pm 3.5$ & $995 \pm 27$ \\
(Increase) & $(\times 4.2)^{* * *}$ & $(\times 4.8)^{* * *}$ & $(\times 6.6)^{* *}$ & $(\times 1.9)$ & $(\times 1.3)$ & $(\times 1.0)$
\end{tabular}

mRNA levels for the neuropeptides were quantified in each individual animal with Northern analysis shown in Figure 2. Radioactivity in Northern blot sheets was measured by a Fuji Bioimage Analyzer (BAS 5000). In general, cDNA probes for the neuropeptide mRNAs were $400-600$ base pairs long and their specific activity was $1-2 \times 10^{\circ} \mathrm{dpm} / \mu \mathrm{g}$ DNA. These experimental conditions allow us to compare roughly the absolute mRNA levels among the neuropeptides. Data represent mean \pm SEM dpm/10 $\mathrm{g}$ RNA $(n=3)$. Statistical analysis was performed using Student's $t$ test for comparison with the values in saline-injected rats.

* $p<0.01$.

** $p<0.005$.

$* * * p<0.001$. 
were less pronounced than those in the ipsilateral hemisphere. Modest but significant increases of ENK-LI and CCK-LI were observed only in limited brain regions; anterior neocortex for both peptides, striatum for CCK-LI and hypothalamus for ENKLI. In summary, the lateral ventricular injection of BDNF increased the neuropeptides most prominently in the anterior neocortex, followed by the posterior neocortex, striatum, hippocampus, and hypothalamus in order of decreasing potency.

\section{Increased expression of $m R N A$ for $N P Y, S O M$, and $S P$ with $B D N F$ administration}

To determine whether the elevation in peptide content was reflected by increased mRNA abundance, we measured mRNA levels for precursors of NPY, SOM, SP, ENK (preproenkephalin $\mathrm{A})$, and $\mathrm{CCK}$ in the anterior neocortex. BDNF or saline was injected twice into the lateral ventricle of newborn rats as described before. RNA was extracted from the anterior neocortex of individual animals and analyzed by RNA blotting (Fig. 2) followed by measurement of a signal intensity (Table 2). The injection of BDNF consistently increased mRNA levels for NPY, SOM, and SP in all animals; the most remarkable increase was observed with SP mRNA followed by NPY and SOM mRNAs, which is in agreement with the results for peptide levels shown in Table 1. In contrast, alteration in mRNA for CCK and ENK was not significant, and $\beta$-actin mRNA as an internal control showed the equality in RNA amounts loaded. The observed alteration in contents of CCK-LI and ENK-LI shown in Table 1 is discrepant with this RNA result. It is possible that BDNF regulated these peptide contents at posttranslational levels by changing the rate of processing their precursor proteins or their synaptic release.

\section{Heterogeneous peptidergic responses of cortical neurons to $B D N F$}

Using immunohistochemical techniques, we examined a qualitative alteration in the expression of the three neuropeptides, NPY, SOM, and SP, whose peptide contents and mRNA levels were both increased by the BDNF injection. On postnatal day 5 , laminar formation in the cortical plate has been almost completed (Berry et al., 1964). Nissl staining showed that neither the cannula insertion nor sample injection disturbed the laminar structure in almost all neocortical regions except the area along the cannula route (Fig. 3).

The peptidergic responses of neurons in the cortical layers were regionally heterogeneous among the neuropeptides, especially in the frontal cortex ipsilateral to the injection site. Intracerebroventricular BDNF markedly increased a frequency of NPY-immunoreactive (NPY-ir) cells with large, ovoid somata in cortical layer IV-VI of the frontal cortex in the BDNFinjected animals in comparison with that in the saline-injected animals (Fig. $4 A, B, E$ ). The strongly NPY-ir cells were also found in the frontoparietal cortex of the BDNF-injected animals. They extended darkly stained radial processes to the surface (Fig. $4 C, G$ ), and resembled the process-bearing NPY-ir cells that are observed in the cortical plate of normal rats from embryonic day 20 until postnatal day 4 (Foster and Schultzberg, 1984; Woodhams et al., 1985). We found another population of BDNFinduced NPY-ir cells, less intensely stained for NPY in layer V in more lateral and dorsal cortex of both hemispheres (Fig. $4 D, F)$. These cells had round somata with large nuclei, presumably corresponding to immature pyramidal neurons.

A number of SOM-ir neurons were induced only in the frontal
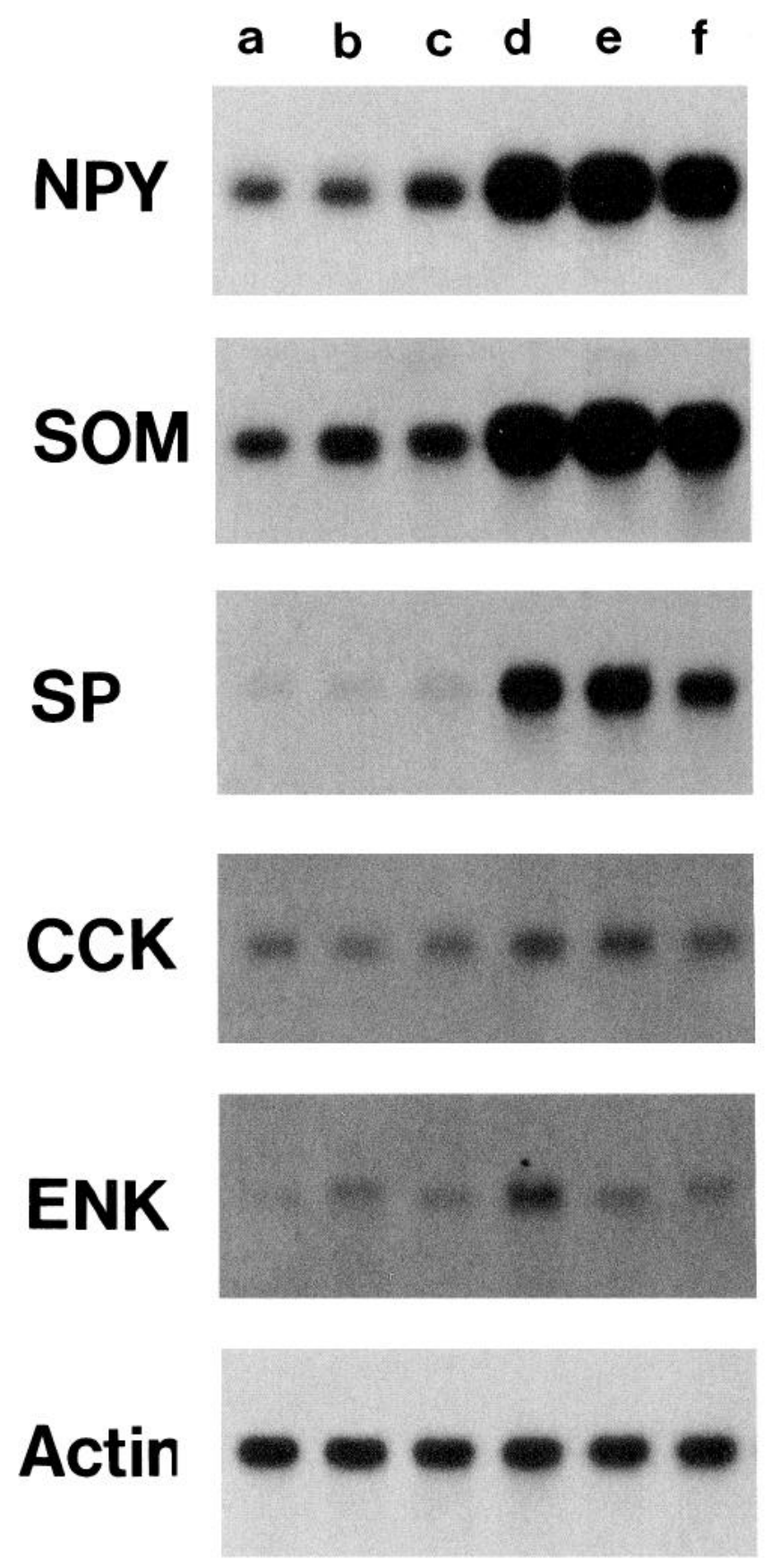

Figure 2. Effects of intraventricular BDNF on neuropeptide mRNAs in the anterior neocortex. Total RNA $(10 \mu \mathrm{g})$ was extracted from the neocortex of individual pups receiving intraventricular saline $(a-c)$ or $\operatorname{BDNF}(d-f)$ twice within $3 \mathrm{~d}$. RNA was separated by $1.2 \%$ agarose gel and transferred onto a nylon membrane. The membrane was probed with cDNA for a NPY precursor. Its autoradiograph was taken for display and radioactivity of band was measured by a Fuji Bioimage Analyzer (see Table 2). After washing the sheet with boiling water, it was rehybridized sequentially with different probes for SOM, SP, CCK, ENK, and $\beta$-actin mRNAs.

cortex of the BDNF-treated rats. They were round and small, lacking any immunoreactive processes and enriched only in the layer VI including the subplate of the frontal cortex near the cannula route (Fig. 5). We did not detect any SOM-ir neurons in the other neocortical regions with given immunostaining procedures. The laminar localization of the induced SOM-ir neu- 

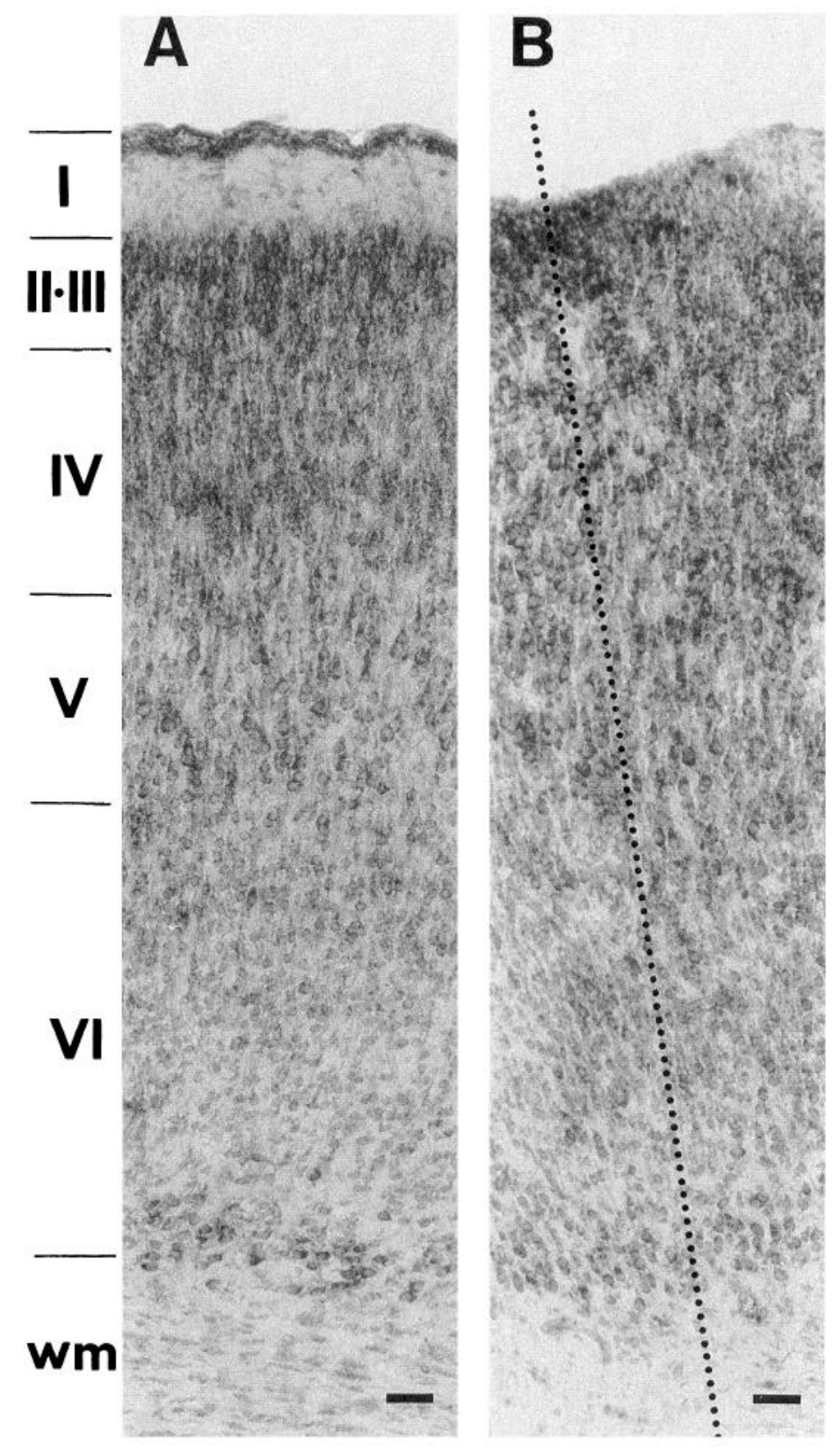
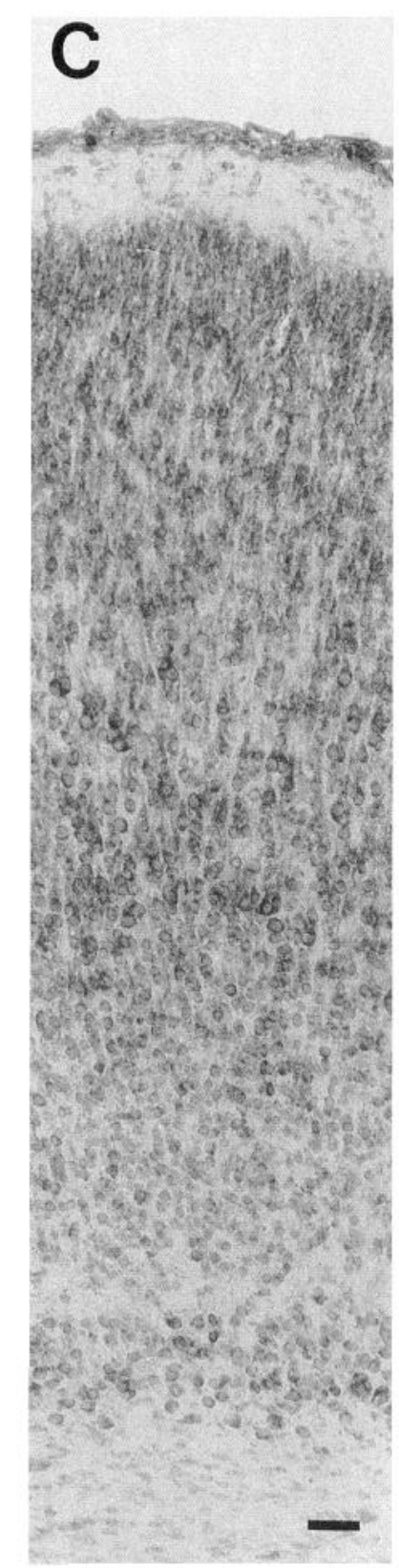

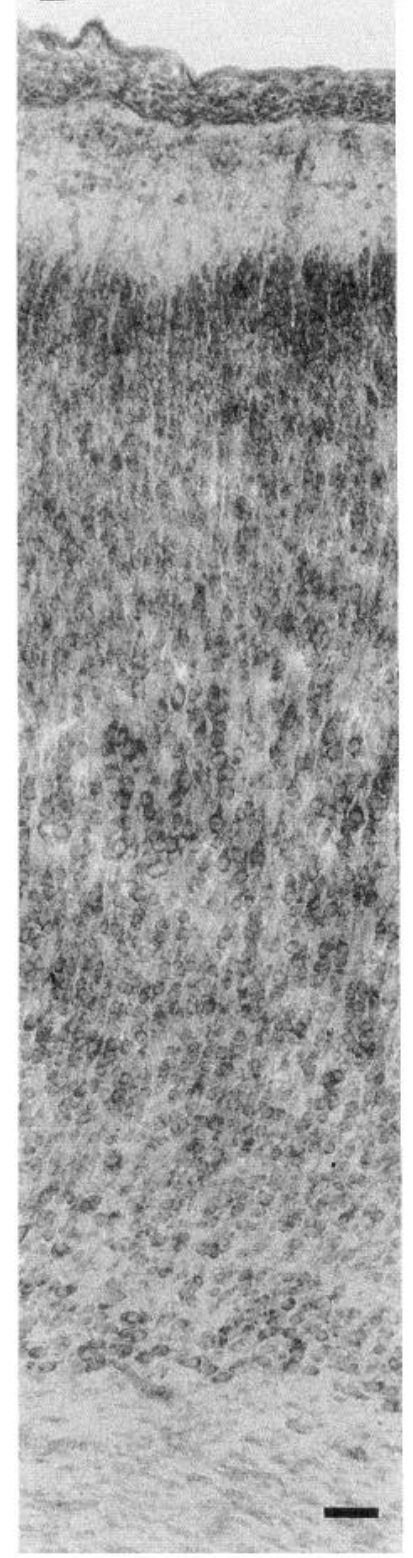

Figure 3. Cortical laminar structure after intraventricular BDNF administration. Coronal brain sections covering the injected site in the anterior frontal cortex were stained with cresyl violet solution. $A$, the frontal cortex contralateral to the saline-injected site (control); $B$, the frontal cortex including cannula route of the BDNF injection; $C$, the frontoparietal cortex ipsilateral to the BDNF-injected site; $D$, frontoparietal cortex contralateral to the BDNF-injected site. The cannula route is indicated by a broken line. Note that the saline injection similarly disturbed the cortical laminar structure along the cannula route (data not shown). Scale bars, $50 \mu \mathrm{m}$.

rons is in agreement with the previous observation in a normal rat: SOM-ir neurons exist in layer VI and the subplate of the visual cortex in first postnatal week, although the frequency of SOM-ir neurons is much lower in normal rats (Eadie et al., 1987).
The induction of SP-LI was most pronounced in layer II/III of the frontal cortex ipsilateral to the BDNF-injected hemisphere (Fig. 6). The somata had pseudo-pyramidal shapes and their cytoplasm and apical dendrites contained most of the immunoreactivity. Punctuate SP-LI was also found in layer V of

Figure 4. Immunohistochemical analysis of NPY-ir neurons in the neocortex. Coronal sections through the neocortex of rats receiving intraventricular saline $(A)$ or BDNF $(B-G)$ were immunostained with anti-NPY antiserum. $A$, the frontal cortex including a cannula route of the saline injection (control); $B$, the frontal cortex adjacent to a cannula route of the BDNF injection; $C$, the frontoparietal cortex ipsilateral to the BDNFinjected site; $D$, frontoparietal cortex contralateral to the BDNF-injected site. Arrowheads mark the layers containing immunoreactivity. $E$, highpower view of strong NPY-ir neurons with ovoid somata in layer IV in the ipsilateral frontal cortex; $F$, high-power view of NPY-ir neurons with large nuclei existing in layer $\mathrm{V}$ in the contralateral parietal cortex; $G$, high-power view of horizontally arranged radial processes originating from layer IV in the frontoparietal cortex. The cannula routes are indicated by broken lines. Scale bars, $50 \mu \mathrm{m}$. 

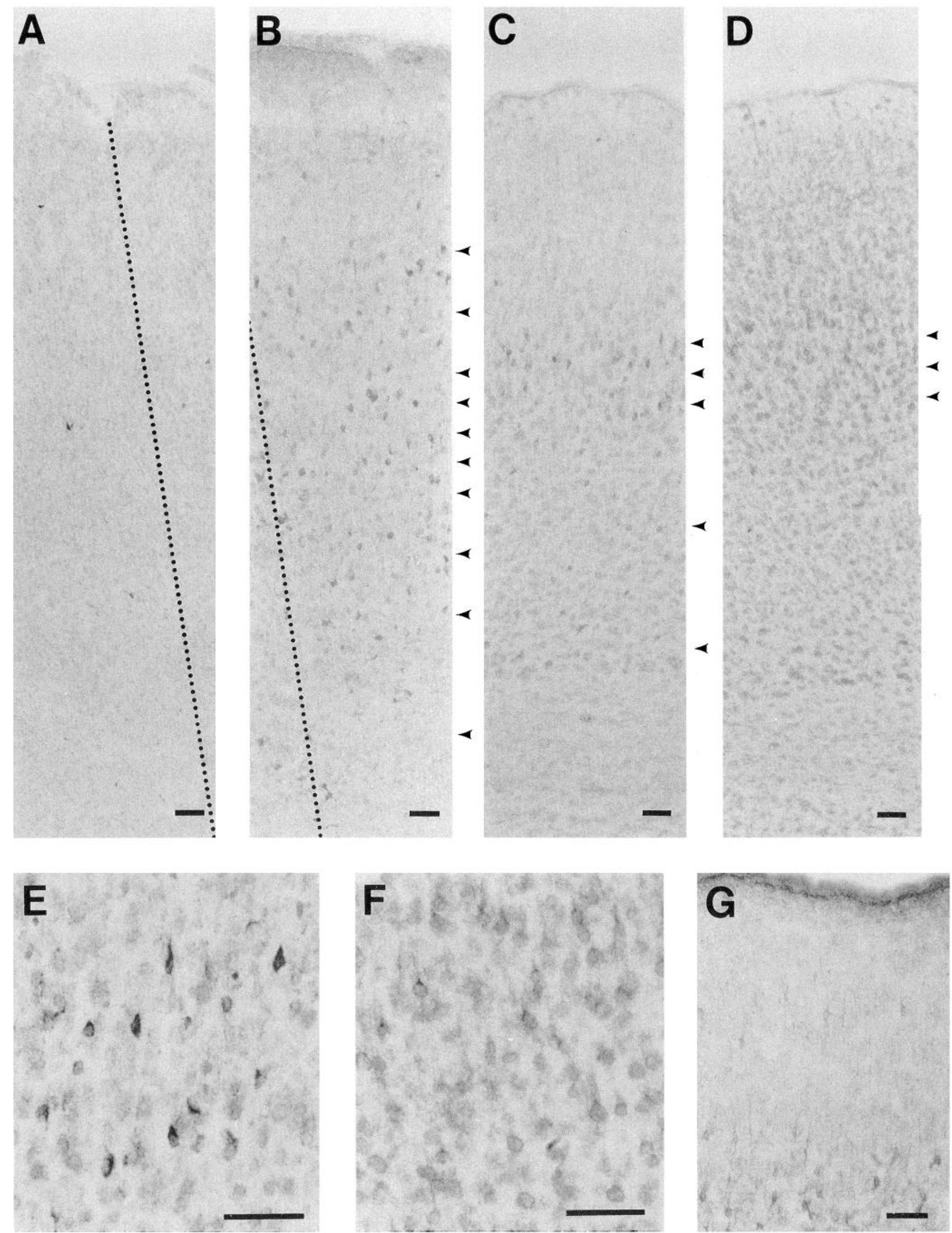

F

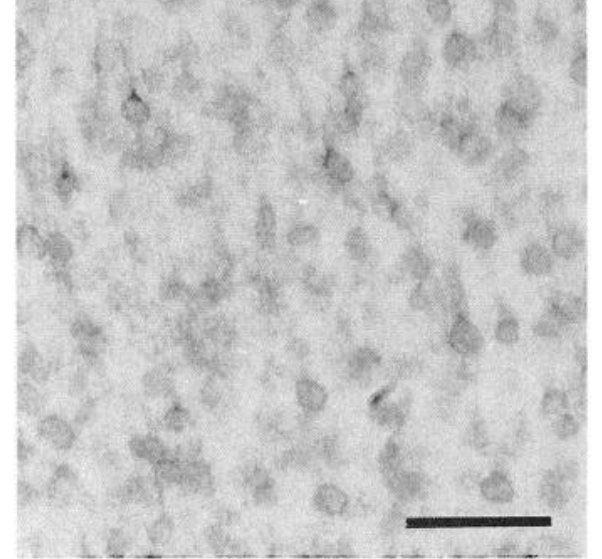

G

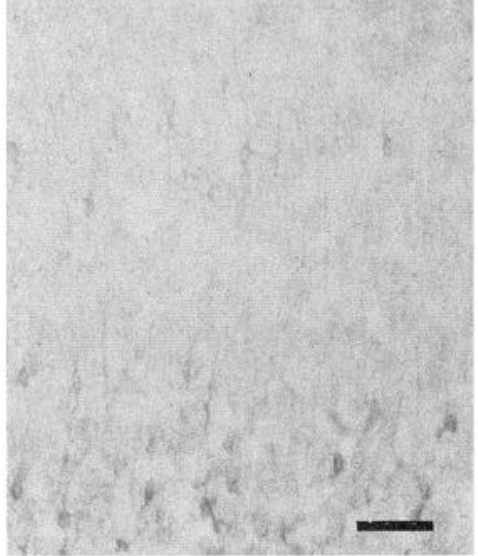




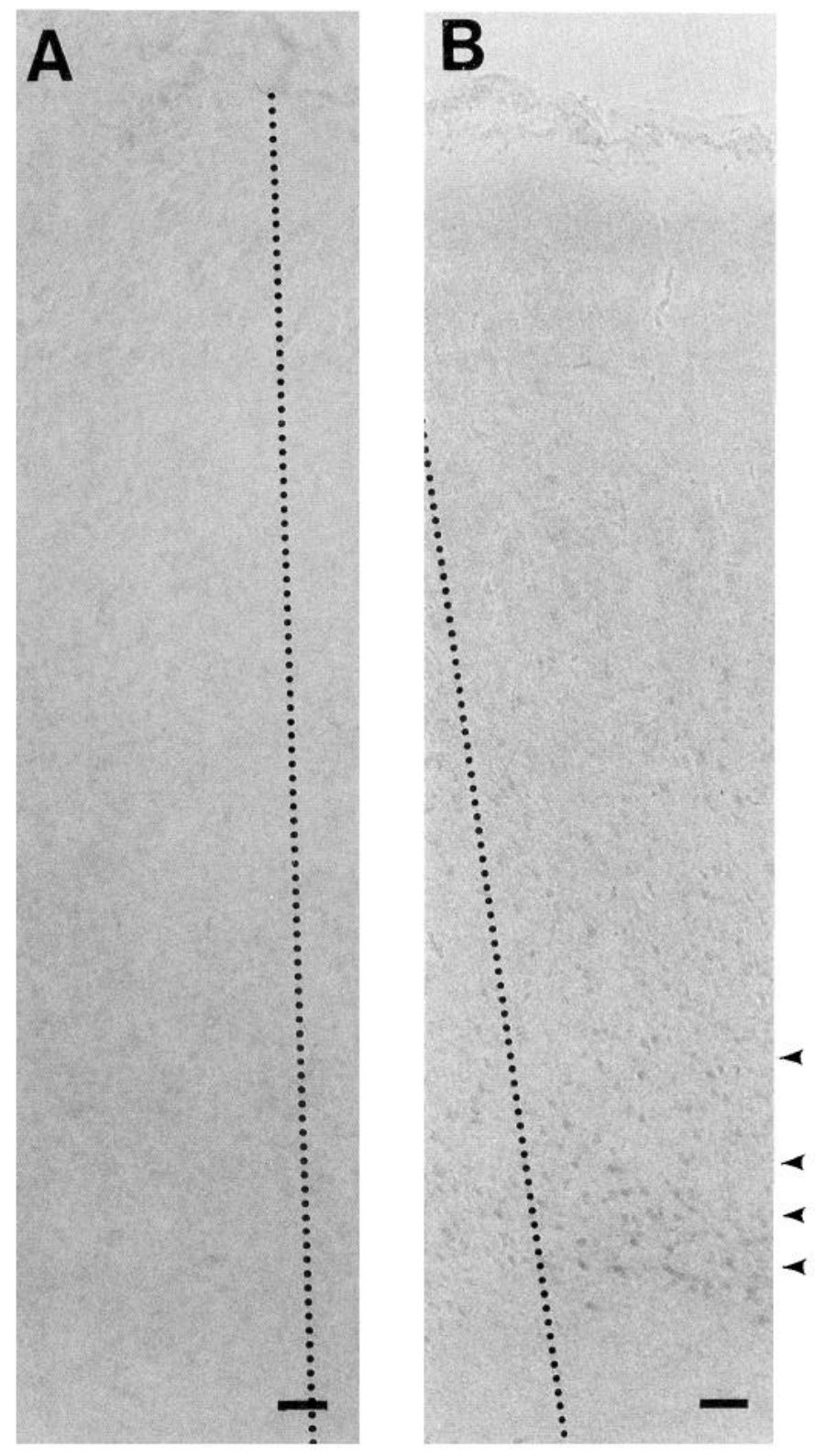

the neocortex in both hemispheres. In the cerebral cortex of embryonic monkey, SP-ir neurons with pyramidal structures are known to develop normally in layer V (Huntley et al., 1988). In addition, relatively large SP-ir neurons coexpressing SOM and/or NPY are observed in layers II-III and VI in adult monkey (Jones et al., 1988). In the neocortex of adult rats, however, only nonpyramidal GABAergic neurons contains SP-LI (Penny et al., 1986). Thus, it remains to be determined whether the BDNF-induced SP-ir neurons in layer II/III exist normally during rat development.

In addition to the cerebral cortex, increased peptide immunoreactivity was also obvious in other brain regions ipsilateral to the BDNF injected hemisphere. Administered BDNF enhanced staining for NPY-LI in the subfield and in hippocampal CA3 stratum pyramidale ipsilateral to the BDNF-injected side. In contrast, the effect of BDNF on neurons in the $\mathrm{CA} 3$ region was less remarkable in the contralateral hemisphere (Fig. $7 A, B$ ) and a few NPY-ir neurons were found only in subfields of the stratum oriens and hilus in saline-injected animal (data not shown). NPY-ir cells are normally seen in the subfield but not found in the CA3 during normal rat development (Foster and Schultzberg, 1984; de Quidt and Emson, 1986). Only extreme conditions such as brain seizures have been shown to induce NPY mRNA in stratum pyramidale (Gall et al., 1991). BDNF also enhanced NPY-LI in thalamic nuclei, striatum and SOMLI in the striatum (Fig. 7A-D). Again, induction of the peptidergic cells was apparent only in the ipsilateral hemisphere, although this observation of SOM-ir cells is controversial with equal regional SOM levels in both hemisphere (Table 1). The NPY-ir cells in the striatum had multipolar processes while SOM-ir neurons had smaller somata lacking immunoreactive processes (Fig. $7 D, F$ ). Overall distribution of the peptide immunoreactivity induced and/or increased by BDNF significantly overlapped with the distribution of endogenous peptide expression found during ontogeny of the rat (NPY, Foster and Schultzberg, 1984; SOM, Shiosaka et al., 1982).

\section{Time course and dose dependency of the peptide increases}

We analyzed the time course of the peptide increases in the neocortex and striatum (Fig. 8). After single injection of BDNF into the lateral ventricle, the anterior neocortex and striatum ipsilateral to the injected side were taken for radioimmunoassay at given time periods. In the anterior neocortex, SP-LI exhibited a very rapid increase after BDNF injection, reaching a plateau level within $12 \mathrm{hr}$ after injection. In contrast, SOM-LI and NPYLI increased linearly with no apparent lag period until $48 \mathrm{hr}$ in the anterior neocortex. In striatum, both peptides displayed a lag period of the induction, but reached the maximum at the same time. Then, all these peptides declined almost to the levels obtained in saline-injected animals during the next $20 \mathrm{hr}$. The temporal profiles of the induction and reduction in the peptide expression parallel closely those observed in neocortical cultures

Figure 5. Immunohistochemical analysis of SOM-ir neurons in the neocortex. Coronal sections through the neocortex of rats receiving BDNF were immunostained with anti-SOM antiserum. $A$, the frontal cortex including a cannula route of the saline injection (control); $B$, the frontal cortex including cannula route of the BDNF injection. Arrowheads mark the layers containing immunoreactivity. $C$, High-power view of SOM-ir neurons with round somata in layer VI of the ipsilateral frontal cortex. The cannula routes are indicated by broken lines. Scale bars, $50 \mu \mathrm{m}$. 
when BDNF was added and subsequently withdrawn (Nawa et al., 1993). The reduction in peptide levels was likely to be caused by clearance (degradation) of the injected BDNF in vivo since BDNF-LI disappeared in the brain $48 \mathrm{hr}$ after injection.

To understand the specificity of the BDNF effects, we also administered the same amount (approximately $7 \mu \mathrm{g}$ ) of NGF as well as various doses of BDNF into the ventricle. Their influence on NPY-LI was analyzed in the anterior neocortex (Fig. 9). NGF did not exhibit a significant effect on NPY-LI. All the other neuropeptide levels were not influenced either (data not shown). In contrast, The $1 / 10$ dose of BDNF (about 700 $\mathrm{ng} /$ animal) still produced an appreciable effect. However, the $\mathrm{l} / 100$ dose of BDNF (about $70 \mathrm{ng} /$ animal) failed to increase NPY-LI. This result suggests that the administered BDNF did not cross-react with the NGF receptors in the above experiments.

\section{Discussion}

In the present study, we have shown that BDNF has a potent neuronal differentiation activity in vivo that increased levels of various neuropeptides in the cerebrum of neonatal rats. In particular, the effects were most prominent for NPY, SP, and SOM: BDNF specifically increased their mRNA levels that presumably led to the enhancement in their de novo synthesis. These observations are consistent with the results obtained previously in cultured neocortical neurons (Nawa et al., 1993). In contrast, the administration of NGF, saline, and control protein into the ventricle did not elicit appreciable effects on these neuropeptides. Therefore, these results suggest that the observed peptidergic increases were produced by administered BDNF rather than mechanical lesions of the injection or nonspecific chemical stimuli in the sample of BDNF. However, we needed relatively high amounts of BDNF to obtain the appreciable effects in vivo. It contrasts well with the fact that only $20 \mathrm{ng} / \mathrm{ml} \mathrm{BDNF}$ was required to produce the maximum increase in NPY levels in cultured neocortical neurons. In many previous studies on BDNF in vivo, however, high amounts of BDNF were often infused into the brain to oblain the significant effects (Alter et al., 1992; Knüsel et al., 1992; Morse et al., 1993). A clear difference of potency in neurotrophins' activities in vivo and in vitro is exemplified by Knüsel et al. (1992): NGF and BDNF appear to be at least 10-30 times less potent at increasing ChAT activity in septal neurons in vivo than those in culture. It has also been known that the maximal effects of cytokines in vivo are often achieved with the infusion of higher doses of cytokines because of their rapid clearance in serum (Flaharty et al., 1990; Kudo et al., 1990). Therefore, it is very likely that neurotrophins also degrade rapidly in vivo, and its effective concentrations can be maintained only for a limited time period.

Interestingly, the BDNF effects displayed spatial and temporal difference among the neuropeptides examined. Heterogeneity in peptidergic responses was most remarkable among the laminar layers in the neocortex. BDNF induced SP-ir neurons in layer II/III, NPY-ir neurons in layers IV-VI and SOM-ir neurons in layer VI. These responses could be interpreted by the following three possibilities. (1) BDNF bound to different receptor species. (2) Neurons in each layer have only limited plasticity as evidenced by the phenotypes induced. (3) The local availability of BDNF differed among the regions. The first possibility might explain a part of the heterogeneous peptidergic responses. BDNF receptors have been identified as trkB gene products (Glass et al., 1991; Klein et al., 1991). The $t r k C$ receptor is thought to be a high-affinity receptor for NT-3 but also can bind to BDNF with relatively high affinity (Soppet et al., 1991). Expression of trkB and trkC mRNAs is initiated in rats beforc birth (Klcin et al., 1989; Ringstedt ct al., 1993). Thus, it is possible that the administrated BDNF reacted to both types of neurotrophin receptors. The expression of $t r k B$ mRNA is observed in all cortical layers including layer $\mathrm{I}$ in the neocortex of both newborn and adult rats. $t r k C$ mRNA is also expressed in all the cortical layers with the highest intensity in layer VI (Merlio et al., 1992; Ringstedt et al., 1993). Since we administered relatively high amounts of BDNF into the brain, it is possible that neurons containing trk $C$ receptors in layer VI also cross-reacted with BDNF and might begin to express somatostatin. The fact that the induction of SOM-LI in the frontal cortex was relatively restricted in the area close to the cannula route might suggest such a possibility.

The second possibility is of limited neuronal plasticity in peptidergic phenotypes: neurotransmitter/peptide phenotypes had substantially been specified in each neuron at birth. This explanation is most likely and reasonably fits with our results for NPY and SOM. The regional distributions and cellular properties of the induced NPY-ir or SOM-ir neurons are almost consistent with those seen in normal development. BDNF simply enhanced the number of NPY-ir and SOM-ir neurons as well as the intensity of the peptide expression. However, there were some exceptions that do not fit into this explanation: SPir neurons induced in cortical layer II/III and NPY-ir neurons in hippocampal pyramidale. In future experiments, we need to explore the unusual peptidergic expression with BDNF and determine its cellular mechanism.

The third possibility is less likely because a high concentration of BDNF-LI was detected throughout all cortical layers around the cannula route. In other neocortical areas, however, local availability of BDNF may be responsible for the laminar-specific peptidergic responses. We found the induction of NPY-LI and SP-LI only in putative pyramidal neurons in parietal cortex in both hemispheres. It is possible that their projecting axons and their terminals absorbed ventricular BDNF and transported it back to their somata (DiStefano et al., 1992). Therefore, only these neurons, whose somata were located even in the BDNF-

\footnotetext{
Figure 6. Immunohistochemical analysis of SP-ir neurons in the neocortex. Coronal sections through the neocortex of rats receiving intraventricular saline $(A)$ or BDNF $(B-F)$ were immunostained with anti-SP antiserum. $A$, the frontal cortex including a cannula route of the saline injection (control); $B$, the frontal cortex ipsilateral to the BDNF-injected site; $C$, the frontoparietal cortex ipsilateral to the BDNF-injected site; $D$, frontoparietal cortex contralateral to the BDNF-injected site. Arrowheads mark the layers containing immunoreactivity. $E$, high-power view of SP-ir cells with pyramidal shaped perikarya in layer II/III of the ipsilateral frontal cortex; $F$, high-power view of SP-ir neurons with large nuclei in layer V in the contralateral frontoparietal cortex. The cannula route is indicated by a broken line. Scale bars, $50 \mu \mathrm{m}$.

Figure 7. Immunohistochemical analysis of neuropeptide induction in other brain regions. Coronal sections through the hippocampus, thalamus, and striatum were immunostained and compared peptidergic immunoreactivity between both hemispheres ipsilateral $(B, D, F)$ and contralateral $(A, C, E)$ to the BDNF-injected site. $A$ and $B$, NPY staining in the hippocampus and lateral thalamus; $C$ and $D, N P Y$ staining in the striatum; and $E$ and $F$, SOM staining in the striatum. $f i$, fimbria hippocampus; $L D$, laterodorsal thalamic nucleus. Scale bars, $50 \mu \mathrm{m}$.
} 


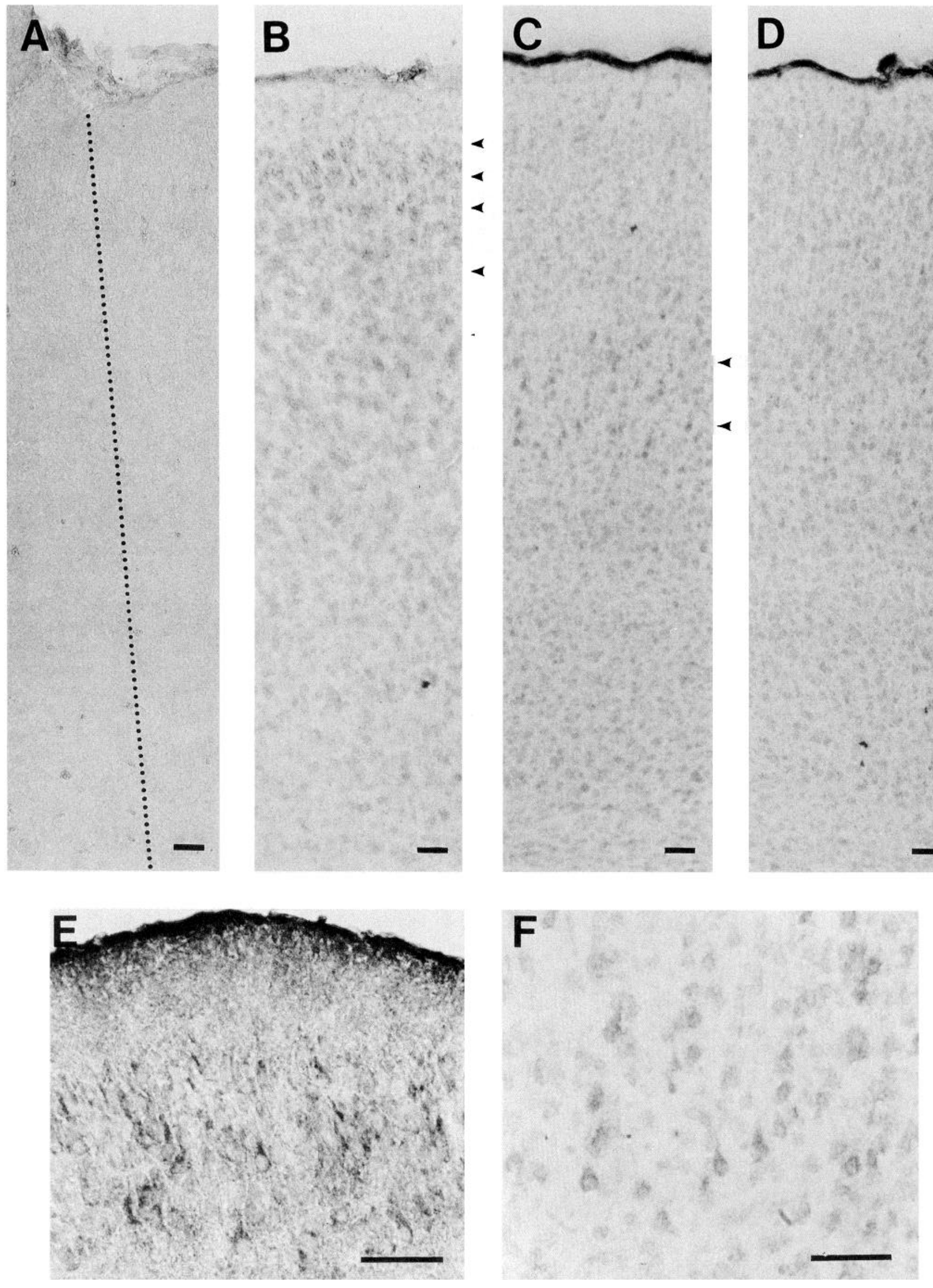



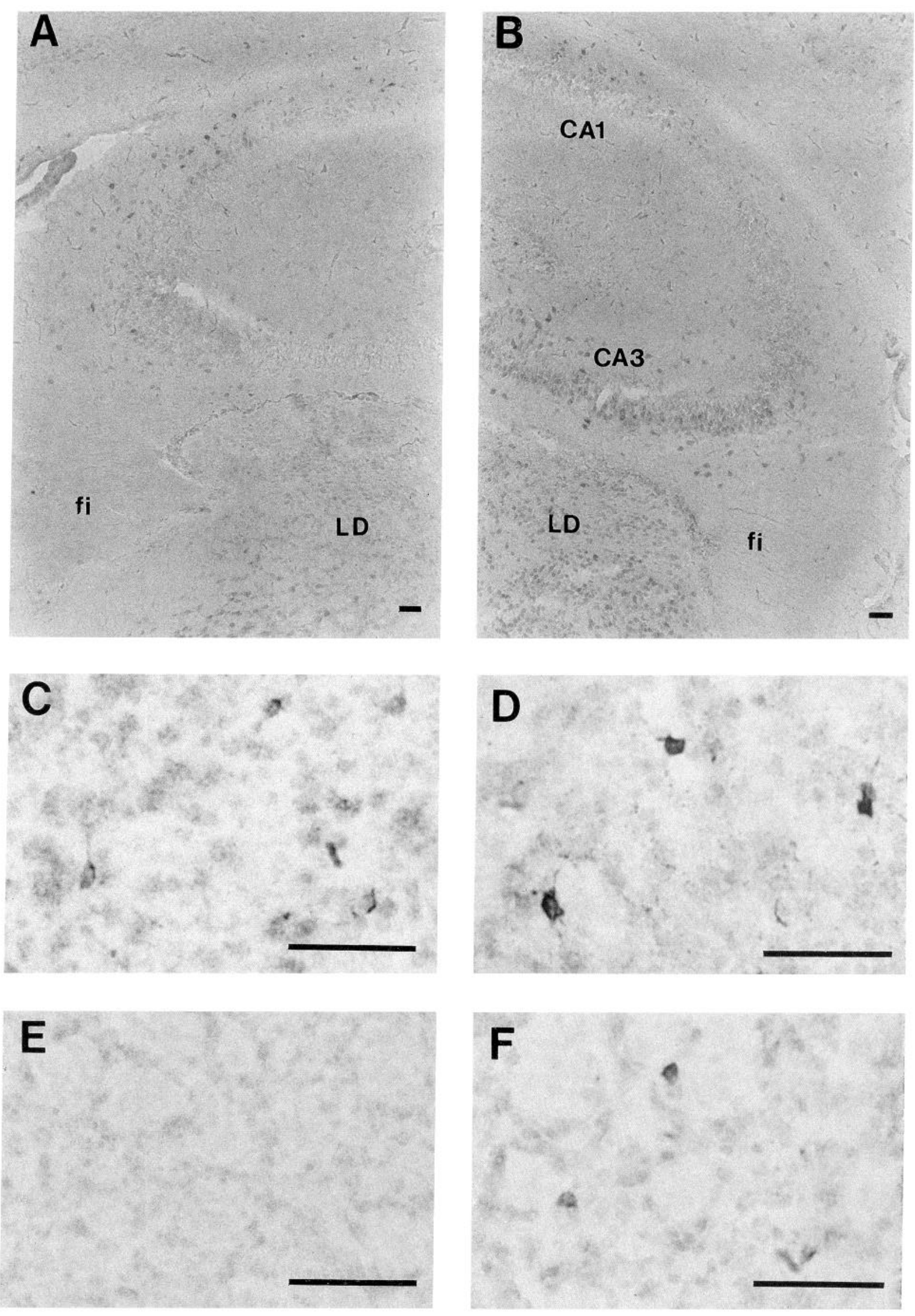

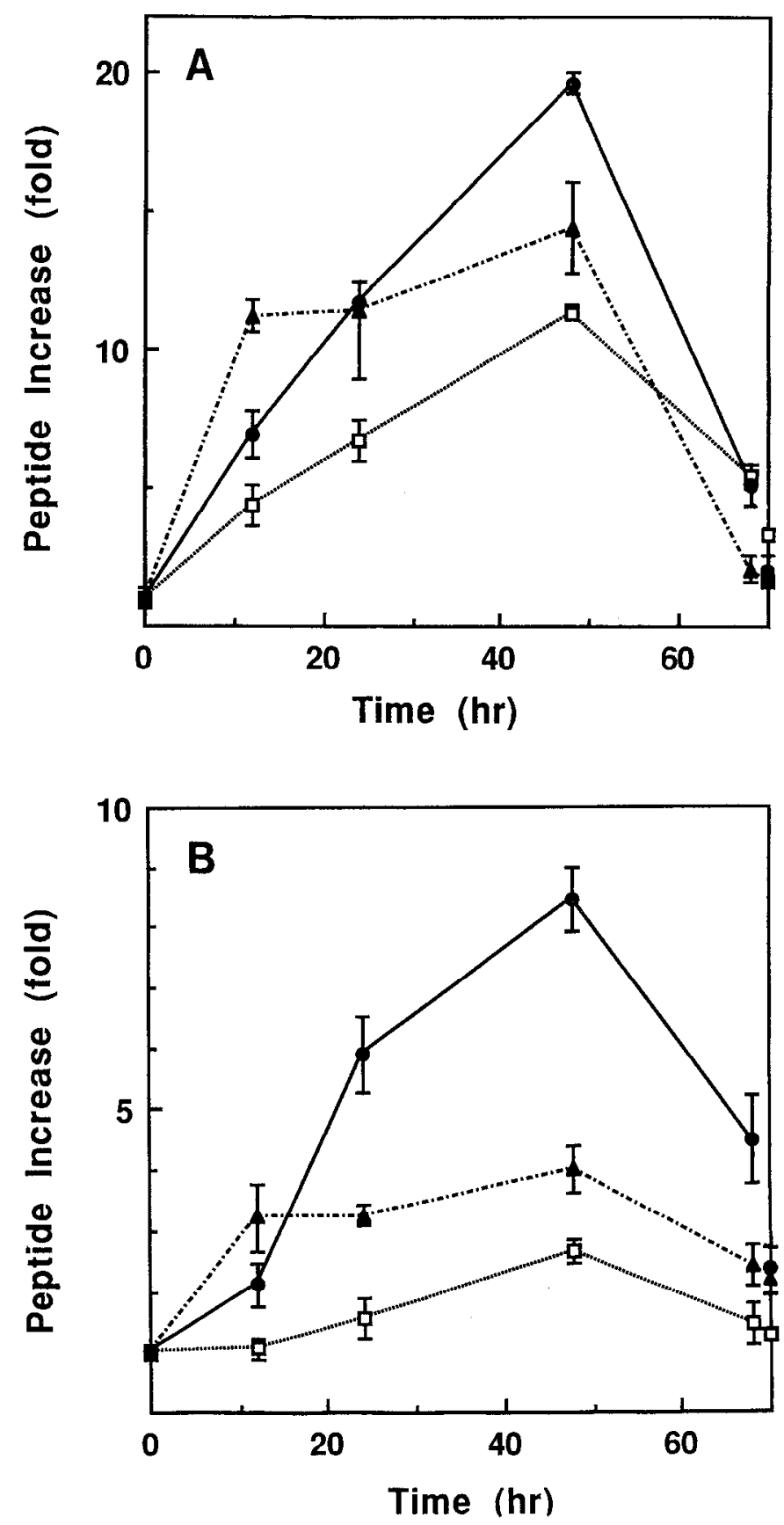

Figure 8. Time course of neuropeptide increases in the anterior neocortex and striatum. At $0,12,24,48$, and $68 \mathrm{hr}$ after BDNF administration, anterior neocortices $(A)$ and striata $(B)$ were taken from the BDNF-injected hemispheres $(n=3)$, and peptides were extracted from these individual tissues. Peptide contents of SP (solid triangles), NPY (solid circles), and SOM (open squares) in the tissue extracts were measured by radioimmunoassay as described in Materials and Methods. Data represent ratios of the peptide contents in BDNF-treated animals to those in unoperated animals of postnatal day 2 . The peptide contents in animals receiving saline injection were measured after $48 \mathrm{hr}$ and their ratios are plotted as controls on the right edge.

deficient brain areas, were able to respond to BDNF and altered their neuropeptide expression.

Similar arguments can be done for the peptidergic responses in other brain regions. Many NPY-ir neurons are known to exist in the hypothalamus (arcuate and median eminence in the hypothalamus) of both newborn and adult rats (Foster and Schultz-

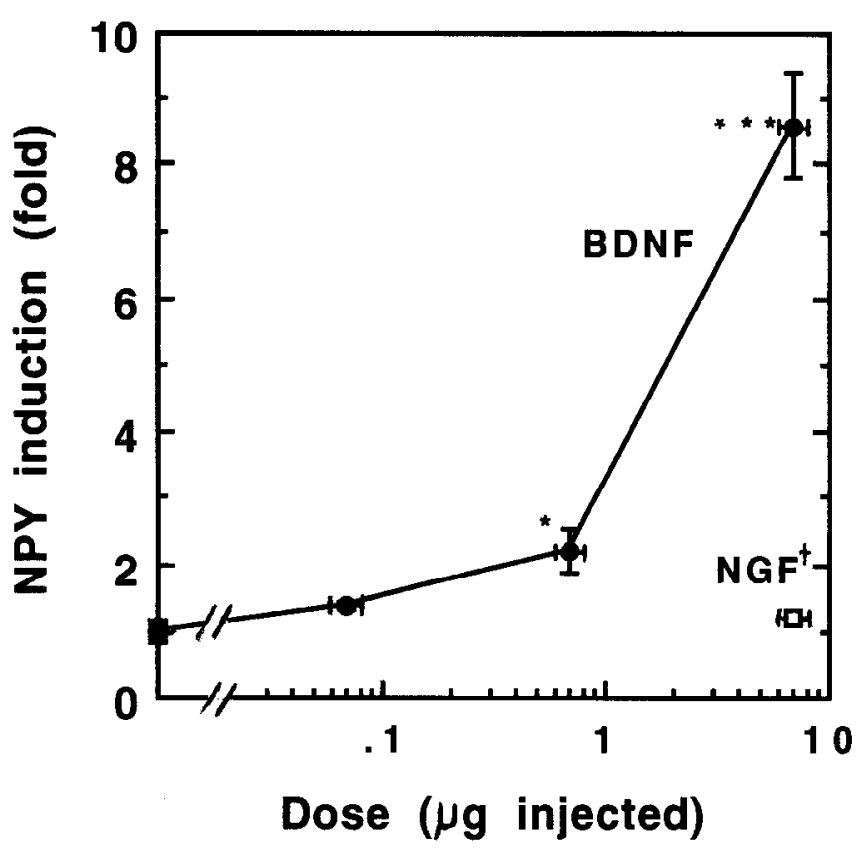

Figure 9. BDNF dose dependency and NGF effect on neuropeptide Y induction. Various doses of BDNF as well as $7.4 \pm 1.1 \mu \mathrm{g}$ of NGF were administered into the ventricle of neonatal rats $(n=4)$ as described above. After $48 \mathrm{hr}$, NPY was extracted from anterior neocortices ipsilateral to the BDNF-injected site, and levels of NPY-LI were determined by radioimmunoassay. Levels of NPY-LI were compared to those in saline-injected animals and their mean ratios to those control values were plotted. $\dagger, \mathrm{NGF}$ failed to exhibit a statistically significant effect on NPY-LI ( $1.20 \pm 0.08$-fold). ${ }^{* * *}, P<0.001 ;{ }^{*}, P<0.01$.

berg, 1984; Woodhams et al., 1985). However, we failed to detect any appreciable influence of BDNF on NPY-LI in the hypothalamus with radioimmunoassay (Table 1) and by immunohistochemistry (data not shown). BDNF has previously been administered into the ventricle of adult rats and was found to have no effect on mesencephalic dopaminergic ncurons (Knüsel et al., 1992), which is controversial with the effects of BDNF directly administered into this region (Alter et al., 1992). This contradiction argues that diffusion of BDNF to the third ventricle was limited and a significant amount of BDNF was not delivered to the hypothalamus. In hypothalamic regions around the third ventricle, however, BDNF-LI was significantly detected in our experiment. Our radioimmunoassay dala demonstrated that hypothalamic neurons have already expressed a high amount of NPY at neonatal stages. The results imply the possibility that, at newborn stages, most of the hypothalamic neurons may have reached their maturity and lost their plasticity in neuropeptide expression. Therefore, they might fail to change NPY levels in response to BDNF.

How can these results be interpreted in peptidergic development of normal rats? In rat CNS, mRNA for BDNF is detected abundantly in most of the brain regions at late embryonic stages (Maisonpierre et al., 1990b; Friedman et al., 1991). The expression of BDNF mRNA is found relatively uniformly in all the neocortical layers as that of $\operatorname{trk} B$ receptor mRNA is. Thus, it is unlikely again that local supply of endogenous BDNF specifies spatial patterns of NPY and SOM expression in normal rats. Our results rather suggest that endogenous BDNF permissively might cnhancc development of the peptidergic expression in the particular neuronal population. Maisonpierre et al.(1990b) 
found abundant expression of NT-3 mRNA in the brain at newborn stages. We have shown that NT-3 also exhibits a similar peptidergic differentiation activity in culture, although the potency of NT - 3 is about 10 times less than that of BDNF (Nawa et al., 1993). Thus, it is possible that endogenous BDNF and NT-3 may both contribute to the peptidergic development in the CNS.

During rat development, the NPY-ir neurons with radial processes emerge in the cortical plate in the frontoparietal (rostrolateral) cortex from embryonic day 17 until postnatal day 4 (Foster and Schultzberg, 1984; Woodhams et al., 1985). Intraventricular administration of BDNF made these neurons reappear in the same region on postnatal day 5 . We have demonstrated that the peptidergic differentiation activity of BDNF is distinct from its neuronal survival promoting activity reported previously on other types of neurons (Nawa et al., 1993). Thus, administered BDNF presumably elevated NPY expression in these transient neurons. Our observations support the idea that these neurons stop the phenotypic expression of NPY rather than they cause cell death in late developmental stages (Woodhams et al., 1985). Such peptidergic neurons with transient appearance have also been identified previously in developing cat telencephalon. These cells are located in the subplate and display NPY-LI or SOM-LI within a limited time period (Chun et al., 1987). It would be intriguing to administer BDNF into cat lateral ventricle and examine its effect on these transient cells.

The excitatory neurotransmitter glutamate enhances BDNF production in cultured hippocampal, neocortical, and cerebellar neurons through different types of glutamate receptors (Zafra et al., 1990, 1991; Bessho et al., 1993). Administration of the glutamate analog, kainate, into the brain induces seizure and increases the expression of BDNF in adult rats (Isackson et al., 1991; Dugich-Djordjevic et al., 1992). Concomitantly, levels of NPY and SOM are increased in the neocortex (Marksteiner and Sperk, 1988; Olenic et al., 1989; Bellmann et al., 1991; Gall et al., 1991), suggesting that neuronal activity can also regulate neuropeptide expression. There are some other evidences for the activity dependency of neuropeptide expression: TTX blockade of visual inputs reduces SP-LI in visual cortex of monkey (Hendry et al., 1988), and repeated electroconvulsive shock increases substance $\mathbf{P}$ expression in ventral periaqueductal gray (Lindefors et al., 1991). The neuropeptides NPY, SOM, and SP increased by neuronal activity are identical to those influenced by BDNF in the present experiment. This coincidence implies that BDNF may mediate the activity-dependent neuropeptide expression, or that BDNF conversely increased neuronal excitability and subsequently elevates the neuropeptide expression. The fact that BDNF, as well as NT-3, acutely enhances neurotransmitter release from nerve terminals of motor neurons (Lohof et al., 1993) might support the latter possibility. In our culture experiments, however, glutamate receptor blockers MK801 and 6-cyano-7-dinitroquinoxaline, or TTX blocked spontaneous neuronal activity (Murphy et al. 1992) but did not prevent the BDNF-mediated induction of NPY and SOM (Nawa et al., 1993; H. Nawa, unpublished observation). This culture result argues that BDNF directly regulates, at least, NPY and SOM expression. Gall et al. (1991) reported an intriguing result on time dependency of seizure-induced neurotrophin and neuropeptide expression. After recurrent limbic seizures, BDNF and NGF mRNAs in the hippocampus exhibit maximal induction within $3 \mathrm{hr}$, while onset of ENK and NPY mRNA induction in the hippocampus lags $3 \mathrm{hr}$ and $6-10 \mathrm{hr}$ behind the neurotro- phin induction, respectively. A potential explanation is that ENK expression is purely activity-dependent while NPY expression is primarily controlled by BDNF. A report that neuronal activity directly regulates ENK expression in culture supports this explanation (Agoston et al., 1991). In this context, the SP induction in the present experiments might be also activity dependent because it similarly exhibited a very rapid onset in its time course. All these observations suggest that there are multiple intercellular signaling pathways that regulate neuropeptide expression in the CNS.

Taking the above discussions together with our present results, we can speculate that neurotrophic factors and neuronal activity mutually interact to each other and control complex neuropeptide expression in the CNS.

\section{References}

Agoston DV, Eiden LE, Brenneman DE (1991) Calcium-dependent regulation of the enkephalin phenotype by neuronal activity during early ontogeny. J Neurosci Res 28:140-148.

Alderson RF, Alterman AL, Barde YA, Lindsay RM (1990) Brainderived neurotrophic factor increases survival and differentiated functions of rat septal cholinergic ncurons in culture. Ncuron 5:297-306.

Allen YS, Adrian TE, Allen JM, Tatemoto K, Crow TJ, Bloom SR, Polak JM (1983) Neuropeptide Y distribution in the rat brain. Science 221:877-879.

Alter CA, Boylan CB, Jackson C, Hershenson S, Miller J, Wiegand SJ, Lindsay RM, Hyman C (1992) Brain-derived neurotrophic factor augments rotational behavior and nigrostriatal dopamine turnover in vivo. Proc Natl Acad Sci USA 89:11347-11351.

Baldino F, Fitzpatrick-McElligott S, O'Kane TM, Gozes I (1988) Hormonal regulation of somatostatin messenger RNA. Synapse 2:317325.

Bannon MJ, Elliott PJ, Bunney EB (1987) Striatal tachykinin biosynthesis: regulation of $\mathrm{mRNA}$ and peptide levels by dopamine agonists and antagonists. Mol Brain Res 3:31-37.

Barde YA, Edgar D, Thoencn H (1982) Purification of a new neurotrophic factor from mammalian brain. EMBO J 1:549-553.

Bellmann R, Widmann R, Olenick C, Meyer DK, Maas D, Marksteiner $J$, Sperk G (1991) Enhanced rate of expression and biosynthesis of neuropeptide $Y$ after kainic acid-induced seizures. J Neurochem 56: 525-530.

Berry M, Rogers AW, Eayrs JT (1964) Pattern of cell migration during cortical histogenesis. Nature 203:591-593.

Bessho Y, Nakanishi S, Nawa H (1993) Glutamate receptor agonists enhance the expression of BDNF mRNA in cultured cerebellar granule cells. Mol Brain Res 18:201-208.

Chun JJM, Nakamura MJ, Shatz CJ (1987) Transient cells of the developing mammalian telencephalon are peptide-immunoreactive neurons. Nature 325:617-620.

Coulombe JN, Schwall R, Parent AS, Eckenstein FP, Nishi R (1992) Induction of somatostatin immunoreactivity in cultured ciliary ganglion neurons by activin in choroid cell-conditioned medium. Neuron 10:899-906.

de Quidt ME, Emson PC (1986) Distribution of neuropeptide Y-like immunoreactivity in the rat central nervous system. II. Immunohistochemical analysis. Neuroscience 18:545-618.

DiStefano PS, Friedman B, Radziejewski C, Alexander C, Boland P, Schick CM, Lindsay RM, Wiegand SJ (1992) The neurotrophins BDNF, NT-3, and NGF display distinct patterns of retrograde axonal transport in peripheral and central neurons. Neuron 8:983-993.

Dugich-Djordjevic MM, Tocco G, Willoughby DA, Najm I, Pasinetti G, Thompson RF, Baudry M, Lapchak PA, Hefti F (1992) BDNF mRNA expression in the developing rat brain following kainic acidinduced seizure activity. Neuron 8:1127-1138.

Eadie LA, Parnavelas JG, Franke E (1987) Development of the ultrastructural features of somatostatin-immunoreactive neurons in the rat visual cortex. J Neurocytol 16:445-459.

Ernsberger U, Sendtner M, Rohrer H (1989) Proliferation and differentiation of embryonic chick sympathetic neurons: effects of ciliary neurotrophic factor. Neuron 2:1275-1284.

Feinberg AP, Vogelstein B (1983) A technique for radiolabelling DNA 
restriction endonuclease fragments to high specific activity. Anal Biochem 132:6-13.

Flaharty KK, Caro J, Erslev A, Whalen JJ, Morris EM (1990) Pharmacokinetics and erythropoietic response to human recombinant erythropoietin in healthy men. Clin Pharmacol Ther 47:557-564.

Foster GA, Schultzberg M (1984) Immunohistochemical analysis of the ontogeny of neuropeptide $\mathrm{Y}$ immunoreactive neurons in foetal rat brain. Int J Dev Neurosci 2:387-407.

Freidin M, Kessler JA (1991) Cytokine regulation of substance P expression in sympathetic neurons. Proc Natl Acad Sci USA 88:32003203.

Friedman WJ, Olson L, Persson H (1991) Cells that express brainderived neurotrophic factor mRNAs in the developing postnatal rat brain. Eur J Neurosci 3:688-697.

Fukada K (1980) Hormonal control of neurotransmitter choice in sympathetic neurone culture. Nature 287:553-555.

Fukada K (1985) Purification and partial characterization of a cholinergic neuronal differentiation factor. Proc Natl Acad Sci USA 82: 8795-8799.

Gall C, Lauterborn J, Bundman M, Murray K, Isackson P (1991) Seizures and the regulation of neurotrophic factor and neuropeptide gene expression in brain. In: Genetic strategies in epilepsy research (Anderson VE, Hauser WA, Leppik IE, Noebels JL, Rich SS, eds), pp 225-245. Amsterdam: Elsevier.

Gerfen CR, McGinty JF, Young WS (1991) Dopamine differentially regulates dynorphin, substance $P$, and enkephalin expression in striatal neurons: in situ hybridization histochemical analysis. J Neurosci 11:1016-1031.

Glass DJ, Nye SH, Hantzopoulos P, Macchi MJ, Squinto SP, Goldfarb M, Yancopoulos GD (1991) TrkB mediates BDNF/NT-3-dependent survival and proliferation in fibroblast lacking the low affinity NGF receptor. Cell 66:405-413.

Hefti F, Hartikka J, Eckenstein F, Gnahn H, Heumann R, Schwab M (1985) Nerve growth factor increases choline acetyl-transferase but not survival or fiber outgrowth of cultured fetal septal cholinergic neurons. Neuroscience 14:55-68.

Hendry SHC, Jones EG, Burstein N (1988) Activity-dependent regulation of tachykinin-like immunoreactivity in neurons of monkey visual cortex. J Neurosci 8:1225-1238.

Higuchi H, Yang HYT, Sabol SL (1988) Rat neuropeptide Y precursor gene expression. J Biol Chem 263:6288-6295.

Hohn A, Leibrock J, Bailey K, Barde YA (1990) Identification and characterization of a novel member of the nerve growth factor/brainderived neurotrophic factor family. Nature 344:339-341.

Hökfelt T (1991) Neuropeptides in perspective: The last ten years. Neuron 7:867-879.

Huntley GW, Hendry SHC, Killackey HP, Chalupa LM, Jones EG (1988) Temporal sequence of neurotransmitter expression by developing neurons of fetal monkey visual cortex. Dev Brain Res 43: 69-96.

Hyatt-Sachs H, Schreiber RC, Bennett TA, Zigmond RE (1993) Phenotypic plasticity in adult sympathetic ganglia in vivo. J Neurosci 13: $1642-1653$

Isackson PJ, Huntsman MM, Murray KD, Gall CM (1991) BDNF mRNA expression is increased in adult rat forebrain after limbic seizures: temporal patterns of induction distinct from NGF. Neuron 6:937-948.

Jonakait GM, Schotland S (1990) Conditioned medium from activatied splenocytes increases substance $P$ in sympathetic ganglia. $J$ Neurosci Res 26:24-30.

Jones EG, DeFelipe J, Hendry SHC, Maggio JE (1988) A study of tachykinin-immunoreactive neurons in monkey cerebral cortex. J Neurosci 8:1208-1224.

Kanazawa I, Jessel T (1976) Post mortem changes and regional distribution of substance $P$ in the rat and mouse nervous system. Brain Res 117:362-367.

Kasper S, Popescu RA, Torsello A, Vrontakis ME, Ikejiani C, Friesen HG (1992) Tissue-specific regulation of vasoactive intestinal peptide messenger ribonucleic acid levels by estrogen in the rat. Endocrinology 130:1796-1801

Klein R, Parada LF, Coulier F, Barbacid M (1989) TrkB, a novel tyrosine protein kinase receptor expressed during mouse neural development. EMBO J 8:3701-3709.

Klein R, Conway D, Parada LF, Barbacid M (1990) The trkB tyrosine protein kinase gene codes for a second neurogenic receptor that lacks the catalytic kinase domain. Cell 61:647-656.
Klein R, Nanduri V, Jing S, Lamballe F, Tapley P, Bryant S, CordonCardo C, Jones KK, Reichardt LF, Barbacid M (1991) The trkB tyrosine kinase is a receptor for brain-derived neurotrophic factor and neurotrophin-3. Cell 66:395-403.

Knüsel B, Winslow JW, Rosenthal A, Burton LE, Seid DP, Nikolics K, Hefti $F$ (1991) Promotion of central cholinergic and dopaminergic neuron differentiation by brain-derived neurotrophic factor but not neurotrophin-3. Proc Natl Acad Sci USA 88:961-965.

Knüsel B, Beck KD, Winslow JW, Rosenthal A, Burton LE, Widmer HR, Nikolics K, Hefti F (1992) Brain-derived neurotrophic factor administration protects basal forebrain cholinergic but not nigral dopaminergic neurons from degenerative changes after axotomy in the adult rat brain. J Neurosci 12:4391-4402.

Kudo S, Mizuno K, Hirai Y, Shimizu T (1990) Clearance and tissue distribution of recombinant human interleukin 1 beta in rats. Cancer Res 50:5751-5755.

Kuhlengel KR, Bunge MB, Bunge RP, Burton H (1990) Implantation of cultured sensory neurons and Schwann cells into lesioned neonatal rat spinal cord. II. Implant characteristics and examination of corticospinal tract growth. J Comp Neurol 293:74-91.

Kuwano R, Araki K, Usui H, Fukui T, Ohtsuka F, Ikehara M, Takahashi Y (1984) Molecular cloning and nucleotide sequence of cDNA coding for rat brain cholecystokinin precursor. J Biochem 96:923-926.

Leibrock J, Lottspeich F, Hohn A, Hofer M, Hengerer B, Masiakowski $\mathrm{P}$, Thoenen H, Barde Y-A (1989) Molecular cloning and expression of brain-derived neurotrophic factor. Nature 341:149-152.

Lindefors N, Brodin K, Stiller CO, Persson H, Brodin E (1991) Repeated electoconvulsive shock increases tachykinin and cholecystokinin mRNA expression in ventral periaqueductal gray. Neuroscience 45:73-80.

Lindsay RM, Harmar AJ (1989) Nerve growth factor regulates expression of neuropeptide genes in adult sensory neurons. Nature 337: 362-364.

Lohof AM, IP NY, Poo MM (1993) Potentiation of developing neuromuscular synapses by neurotrophins NT -3 and BDNF. Nature 363 : 350-353.

Maisonpierre PC, Belluscio L, Squinto S, Ip NY, Furth ME, Lindsay RM, Yancopoulos GD (1990a) Neurotrophin-3: a neurotrophic factor related to NGF and BDNF. Science 247:1446-1451.

Maisonpierre PC, Belluscio L, Friedman B, Alderson RF, Wiegand SJ, Furth ME, Lindsay RM, Yancopoulus GD (1990b) NT-3, BDNF, and NGF in the developing rat nervous system: parallel as well as reciprocal patterns of expression. Neuron 5:501-509.

Marksteiner J, Sperk G (1988) Concomitant increase of somatostatin, neuropeptide $\mathrm{Y}$ and glutamate decarboxylase in the frontal cortex of rats with decreased seizure threshold. Neuroscience 26:379-385.

Martinez HJ, Dreyfus CF, Jonakait GM, Black IB (1985) Nerve growth factor promotes cholinergic development in brain striatal cultures. Proc Natl Acad Sci USA 82:7777-7781

Merlio JP, Ernfors P, Jaber M, Persson H (1992) Molecular cloning of rat $t r k C$ and distribution of cells expressing messenger RNAs for members of the $t r k$ family in the rat central nervous system. Neuroscience 51:513-532.

Mobley WC, Rutkowski JL, Tennekoon GI, Buchanan K, Johnston MV (1985) Choline acetyltransferase activity in striatum of neonatal rats increased by nerve growth factor. Science 229:284-287.

Morse JK, Wiegand SJ, Anderson K, You Y, Cai N, Carnahan J, Miller J, DiStefano PS, Alter CA, Lindsay RM, Alderson RF (1993) Brainderived neurotrophic factor (BDNF) prevents the degeneration of medial septal cholinergic neurons following fimbria transection. J Neurosci 13:4146-4156.

Murphy TH, Blatter LA, Wier WG, Baraban JM (1992) Spontaneous synchronous synaptic calcium transients in cultured cortical neurons. J Neurosci 12:4834-4845.

Nawa H, Sah DWY (1990) Differential biological activities in conditioned media control the expression of a variety of neuropeptides in cultured sympathetic neurons. Neuron 4:279-287.

Nawa H, Yamamori Y, Le T, Patterson PH (1990) Generation of neuronal diversity: analogies and homologies with hemidopoiesis. Cold Spring Harbor Symp Quant Biol 55:247-252.

Nawa H, Bessho Y, Carnahan J, Nakanishi S, Mizuno K (1992) Regulation of peptide expression in cultured cortical neurons by BDNF. Soc Neurosci Abstr 18:106.11.

Nawa H, Bessho Y, Carnahan J, Nakanishi S, Mizuno K (1993) Regulation of neuropeptide expression in cultured cerebral cortical neurons by brain-derived neurotrophic factor. J Neurochem 60:772-775. 
Olenik C, Meyer DK, Marksteiner J, Sperk G (1989) Concentrations of mRNAs encoding for preprosomatostatin and preprocholecystokinin are increased after kainic acid-induced seizures. Synapse 4:223228.

Patterson PH, Nawa H (1993) Neuronal differentiation factors/cytokines and synaptic plasticity. Cell 72/Neuron 10[Suppl]:123-137.

Paxinos G, Tork I, Tecott LH, Valentino KL (1991) Atlas of the developing rat brain. San Diego, CA: Academic.

Penny GR, Afsharpour S, Kitai ST (1986) Substance P-immunoreactive neurons in the neocortex of the rat: a subset of the glutamic acid decarboxylase-immunoreactive neurons. Neurosci Lett 65:53-59.

Rao MS, Tyrrell S, Landis SC, Patterson PH (1992) Effects of ciliary neurotrophic factor (CNTF) and depolarization on neuropeptide expression in cultured sympathetic neurons. Dev Biol 150:281-293.

Ringstedt T, Lagercrantz H, Persson H (1993) Expression of members of the $t r k$ family in the developing postnatal rat brain. Dev Brain Res 72:119-131.

Saadat S, Semdtmer M, Rohrer H (1989) Ciliary neurotrophic factor induces cholinergic differentiation of rat sympathetic neurons in culture. J Cell Biol 108:1807-1816.

Sambrook J, Fritsch EF, Maniatis T (1989) Molecular cloning; a laboratory manual. Cold Spring Harbor, NY: Cold Spring Harbor Laboratory.

Shadiack AM, Hart RP, Jonakait GM (1992) Leukemia inhibitory factor mediates the interleukin- 1 induction of substance $P$ in sympathetic ganglia. Soc Neurosci Abstr 18:547.4.

Shiosaka S, Takatsuki K, Sakanaka M, Inagaki S, Takagi H, Senba E, Kawai $Y$, lida $H$, Minagawa $H$, Hara $Y$, Matsuzaki T, Tohyama $M$ (1982) Ontogeny of somatostatin containing neuron system of the rat: immunohistochemical analysis. II. Forebrain and diencephalon. J Comp Neurol 204:211-224.

Simerly RB, Swanson LW (1987) Castration reversibly alters levels of cholecystokinin immunoreactivity within cells of three interconnected sexually dimorphic forebrain nuclei in the rat. Proc Natl Acad Sci USA 84:2087-2091.

Simerly RB, Young BJ, Capozza MA, Swanson LW (1989) Estrogen differentially regulates neuropeptide gene expression in a sexually dimorphic olfactory pathway. Proc Natl Acad Sci USA 86:47664770.

Soppet D, Escandon E, Maragos J, Middlemas DS, Reis SW, Blair J, Burton LE, Stanton BR, Kaplan DR, Hunter T, Nikolics K, Parada LF (1991) The neurotrophic factors brain-derived neurotrophic factor and neurotrophin-3 are ligands for the trk $\mathrm{B}$ tyrosine kinase receptor. Cell 65:895-903.

Tempel A, Kessler JA, Zukin RS (1990) Chronic naltrexone treatment increases cxpression of preproenkephalin and preprotachykinin mRN $\Lambda$ in discrete brain regions. J Neurosci 10:741-747.

Wahlestedt C, Karoum F, Jaskiw G, Wyatt RJ, Larhammar D, Ekman $R$, Reis D (1991) Cocaine-induced reduction of brain neuropeptide $Y$ synthesis dependent on medial prefrontal cortex. Proc Natl Acad Sci USA 88:2078-2082.

Woodhams PL, Allen YS, McGovern J, Allen JM, Bloom SR, Balazs R, Polak JM (1985) Immunohistochemical analysis of the early ontogeny of the neuropeptide $\mathrm{Y}$ system in rat brain. Neuroscience 15:173-202.

Yamamori T, Fukada K, Aebersold R, Korsching S, Fann M, Patterson PH (1989) The cholinergic neuronal differentiation factor from heart cells is identical to leukemia inhibitory factor. Science $246: 1412-$ 1416.

Yancopoulos GD, Maisonpierre PC, Ip NY, Aldrich TH, Belluscio L, Boulton TG, Cobb MH, Squinto SP, Furth ME (1990) Neurotrophic factors, their receptors, and the signal transduction pathways they activate. Cold Spring Harbor Symp Quant Biol 55:371-379.

Zafra F, Hengerer B, Leibrock J, Thoenen H, Lindholm D (1990) Activity dependent regulation of BDNF and NGF mRNAs in the rat hippocampus is mediated by non-NMDA glutamate receptors. EMBO J 9:3545-3550.

Zafra F, Castren E, Thoenen H, Lindholm D (1991) Interplay between glutamate and $\gamma$-aminobutyric acid transmitter systems in the physiological regulation of brain-derived neurotrophic factor and nerve growth factor synthesis in hippocampal neurons. Proc Natl Acad Sci USA 88:10037-10041. 